Priscila de Abreu Rocha

\title{
Efeito da óxido nítrico sintase na dor neuropática
}

Dissertação apresentada ao Programa de PósGraduação em Ciências Morfofuncionais do Departamento de Anatomia do Instituto de Ciências Biomédicas da Universidade de São Paulo, para obtenção do Título de Mestre em Ciências Morfofuncionais. 
Priscila de Abreu Rocha

\section{Efeito da óxido nítrico sintase na dor neuropática}

Dissertação apresentada ao Programa de PósGraduação em Ciências Morfofuncionais do Departamento de Anatomia do Instituto de Ciências Biomédicas da Universidade de São Paulo, para obtenção do Título de Mestre em Ciências Morfofuncionais.

Área de concentração: Ciências Morfofuncionais.

Orientador: Prof ${ }^{a}$. Dr ${ }^{a}$. Marucia Chacur

Versão Original

São Paulo

2011 
DADOS DE CATALOGAÇÃO NA PUBLICAÇÃO (CIP)

Serviço de Biblioteca e Informação Biomédica do

Instituto de Ciências Biomédicas da Universidade de São Paulo

(c) reprodução total

Rocha, Priscila de Abreu.

Efeito da óxido nítrico sintase na dor neuropática / Priscila de Abreu Rocha. -- São Paulo, 2011.

Orientador: Marucia Chacur.

Dissertação (Mestrado) - Universidade de São Paulo. Instituto de Ciências Biomédicas. Departamento de Anatomia. Área de concentração: Ciências Morfofuncionais. Linha de pesquisa: Dor neuropática.

Versão do título para o inglês: Effect of nitric oxide synthase in neuropathic pain

Descritores: 1. Dor 2. Modelos animais de doenças 3. Doenças do sistema nervoso em animal 4. Neuroanatomia de animal 5. Neurofisiologia 6. Farmacologia experimental I. Chacur, Marucia II. Universidade de São Paulo. Instituto de Ciências Biomédicas. Programa de Pós-Graduação em Ciências Morfofuncionais III. Título. 
Título da Dissertação: $\quad$ Efeito da óxido nítrico sintase na dor neuropática.

Orientador(a): Marucia Chacur.

A Comissão Julgadora dos trabalhos de Defesa da Dissertação de Mestrado, em sessão pública realizada a ..................................,
( ) Aprovado(a)
( ) Reprovado(a)

Examinador(a): Assinatura: Nome completo: Instituição:

Examinador(a): Assinatura:

Nome completo:

Instituição:

Presidente: Assinatura:

Nome completo:

Instituição: 
Certificamos que o protocolo registrado sob $\mathrm{n}^{\circ} 29$ nas fls. 68do livro 02 para uso de animais em experimentação, sob a responsabilidade do $\operatorname{Prof}(a) \operatorname{Dr}(a)$ Marucia Chacur, Coordenador(a) da Linha de pesquisa Efeito da óxido nítrico sintase na dor neuropática do qual participou(aram) o(s) alunos Aline Carolina Giardini e Priscila de Abreu Rocha e o pesquisador Luiz R.G.Britto, está de acordo com os Principios Éticos de Experimentaçāo Animal adotado pela Sociedade Brasileira de Ciência de Animais de Laboratório (SBCAL) e foi aprovado pela COMISSÃO DE ÉTICA EM EXPERIMENTAÇÃO ANIMAL (CEEA) em 26.03.09, com validade de 3 anos.

São Paulo, 27 de março de 2009.

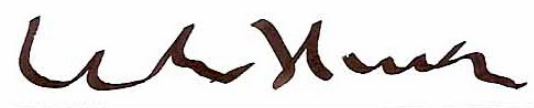

Prof.Dr.Wothan TAVARES DE LIMA Coordenador CEEA - ICB/USP

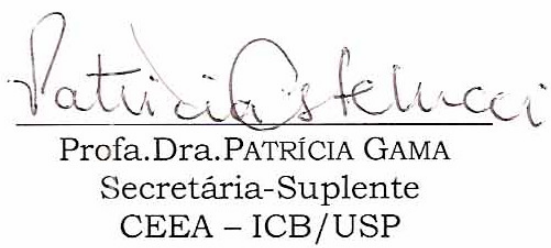


Dedico este trabalho a todos os queridos que moram em meu coração, em especial, aos meus pais Daisy e Rocha, aos meus filhos Luan e a Estela que está por vir, vocês são essenciais à minha existência. Obrigada todos os dias!!! 


\section{AGRADECIMENTOS}

Ao Departamento de Anatomia do Instituto de Ciências Biomédicas da universidade de São Paulo, por ter oferecido os recursos necessários para realização desta pesquisa e a Comissão de Aperfeiçoamento de Ensino Superior (CAPES), pelo auxílio financeiro para realização deste trabalho.

À Prof. Marucia Chacur pela aceitação, confiança e disposição em me aguentar, serei eternamente grata. Por todas as oportunidades de aprendizagem que muito contribuíram para a minha formação profissional. "Maru (chefa), mora em meu coração, você, Paulo e Luana, coisica mais fofa e cheia de luz".

Aos meus amigos de laboratório e de vida, Aline (li, lizandra, lizelda, little flower), Daniel (dani), Joice (jojó), Fábio, Mara, Milena (pretinha, mimi) e Regina (rê) que formam o time do lab de neurodor (Laboratório de Neuroanatomia Funcional da Dor) mais incrivelmente delicioso de se trabalhar, obrigada por todos os momentos de aprendizado, companheirismo e diversão que me proporcionaram. A Wilma (wiiil), amiga querida e agregada oficial de nosso lab, obrigada pelo carinho e confiança. Ao Arnold, nosso querido estagiário, amigo e colaborador, obrigada por tudo. Amo todos vocês, muitão, estarão sempre comigo. E para terminarmos como iniciamos, hehe, harmonia e luz, sempreee!!!

Ao Prof. Luis Roberto G. Britto do Laboratório de Neurofisiologia Celular pelos ensinamentos, confiança e por disponibilizar o laboratório, o inicio da minha pesquisa só foi possível devido a essa oportunidade, muito obrigada! Ao Adilson (didios) técnico deste laboratório que me ensinou muito e me fez rir muito também, pessoa iluminada que mora em meu coração. A todas as pessoas que por lá passaram e que lá estão, em especial a Rô (atualmente pesquisadora no IEP/Hospital Sírio-Libanês, que muito me ensinou desde o inicio), Juju (querida do coração que me ensinou e ajudou muito, super obrigada pelo incentivo e carinho), Aninha (pelos ensinamentos, paciência e colaboração essencial para que parte deste projeto pudesse ser realizada), Marina, Mauro, Paulinha, Érika, Carol, Vivian, Kallene e Cecília, obrigada pelos ensinamentos, contribuições e carinho. Cada um de vocês, à sua maneira, contribuiu de forma indispensável para este processo.

À Prof. Andréa da Silva Torrão e a todos do laboratório de comunicação neural, em especial a Tata, Gabi e Caio, pelos ensinamentos, contribuições, bons momentos e por disponibilizar o laboratório para que pudesse iniciar este processo. 
Ao Prof. Jackson Cione Bittencourt e a Prof. Luciane Sitta pelos ensinamentos e boa vontade com que disponibilizou o laboratório e materiais para que parte deste trabalho pudesse ser realizado. Ao pessoal do Laboratório de Neuroquímica ou que por ali passaram, em especial a Jô, Amanda, Renatinha, Dani, Kelly, Carlão, Fernando, André, Helder e Marina, muito obrigada por tudo, desde as boas conversas, cafés e risadas até os ensinamentos, contribuições e ajuda nos momentos de desespero e não desespero também, foram imprescindíveis para todo o processo. Ao meu amigo que não é deste laboratório mais conheci e convivi durante o seu pós-doc por aqui, Marcus, que além de maluco é uma pessoa mais que especial, muitíssimo obrigada pelos ótimos momentos, pelas importantes conversas, pelo carinho e amizade, você é um zé mas eu te amo!

À Prof. Elen Haruka Miyabara e a todos do Laboratório de Plasticidade Músculo-Esquelética, foram inúmeras as contribuições para a realização de Western blot, que permitiram desenvolver grande parte deste trabalho.

Á Prof. Maria Luiza Morais Barreto de Chaves, pelos ensinamentos e por possibilitar a realização de parte deste processo. Ao pessoal do Laboratório de Biologia Celular e Anatomia Funcional pelas muitas contribuições extremamente significativas e bons momentos, em especial à Dayane que muito me ensinou sobre Western e ao Felix pelos ensinamentos de vida, amizade e carinho.

Ao Prof. Newton Canteras pelos ensinamentos e por possibilitar o uso do microscópio inúmeras vezes. A todos do Laboratório de Neuroanatomia Funcional por todas as contribuições e ensinamentos. Em especial, ao amigo Cleyton (catinho), muito querido, por todos os momentos, do trabalho ao lazer, você é especial e mora em meu coração.

A todos os docentes, funcionários e alunos do departamento de anatomia que de alguma maneira foram essenciais para que tudo pudesse acontecer, as moças da limpeza por deixarem tudo bonito e cheirosinho, aos moços da manutenção que tanto pentelhei quando cheguei aqui e que sempre foram muito gentis comigo, ao pessoal da copa pelo delicioso café de cada dia, aos moços do biotério que além de cuidar dos meus ratos me aguentavam lavando avental, aos porteiros e seguranças por cuidarem de tudo e de mim por muitos dias e noites neste departamento, as moças da secretaria que tanto me tiraram dúvidas, enfim, a todos, um por um, muitíssimo obrigada, cada qual com seu papel é imprescindível para o todo!!!!

Aos professores que muito me ensinaram nas disciplinas realizadas durante esse processo. Um super obrigada ao querido Prof Antonio Carlos Cassola pela imensa e significativa contribuição para minha formação profissional e também humana, mora em meu coração para todo sempre!!! 
Aos Professores Jackson e Soraia e a pesquisadora Rosana, por terem constituído a banca do exame de qualificação e pelas relevantes apreciações emitidas naquela ocasião.

Aos professores constituintes da banca examinadora, pela atenção dispensada na leitura desta dissertação e na defesa.

Aos familiares e amigos de vida, desde a minha infância até hoje, são muitos os queridos que fizeram e fazem toda a diferença para eu ser o que sou por isso não citarei um por um, pois, poderia deixar algum nome de fora e isso seria injusto, tenho em mim um pouco de cada um de vocês, agradeço todos os dias por serem quem são, por fazerem parte da minha existência e me ajudarem a construir a minha história.

Muitíssimo obrigada todos os dias!!! 
É mais fácil

Cultuar os mortos

Que os vivos

Mais fácil viver

De sombras que de sóis

É mais fácil

Mimeografar o passado

Que imprimir o futuro...

Não quero ser triste

Como o poeta que envelhece

Lendo Maiakóvski

Na loja de conveniência

Não quero ser alegre

Como o cão que sai a passear

Com o seu dono alegre

Sob o sol de domingo...

Nem quero ser estanque

Como quem constrói estradas

E não anda

Quero no escuro

Como um cego tatear

Estrelas distraídas

Quero no escuro

Como um cego tatear

Estrelas distraídas...

Amoras silvestres

No passeio público

Amores secretos

Debaixo dos guarda-chuvas

Tempestades que não param

Pára-raios quem não tem

Mesmo que não venha o trem

Não posso parar

Tempestades que não param

Pára-raios quem não tem

Mesmo que não venha o trem

Não posso parar...

Veja o mundo passar

Como passa

Uma escola de samba

Que atravessa

Pergunto onde estão

Teus tamborins?

Pergunto onde estão

Teus tamborins?

Sentado na porta

De minha casa

A mesma e única casa

A casa onde eu sempre morei

A casa onde eu sempre morei A casa onde eu sempre morei... 


\section{RESUMO}

Rocha PA. Efeito da Óxido Nítrico Sintase na dor neuropática. [dissertação (Mestrado em Ciências Morfofuncionais)] - Instituto de Ciências Biomédicas, Universidade de São Paulo, São Paulo, 2011.

A lesão do nervo periférico resulta em dor neuropática persistente ou crônica, caracterizada por dor espontânea em queimação, acompanhada de alodinia e hiperalgesia. A ocorrência de alterações patológicas no sistema nervoso periférico e na medula espinal contribui para o desenvolvimento da dor neuropática. Estas alterações incluem descargas ectópicas nas fibras nervosas periféricas lesadas, as quais mantêm os impulsos nervosos aferentes para o sistema nervoso central. Várias substâncias sintetizadas e/ou liberadas durante o processo inflamatório tais como cininas, neuropeptídeos, citocinas, óxido nítrico, entre outros, assim como as alterações morfofuncionais celulares, podem interferir com a atividade dessas fibras. Estas alterações na homeostasia do indivíduo podem implicar em uma perda da qualidade de vida do paciente. Portanto, tais informações são essenciais para o auxílio de uma terapia analgésica eficiente e/ou preventiva. Assim, o presente projeto tem como objetivo compreender melhor a participação das isoformas neuronal e induzível em modelo de dor neuropática induzida pela lesão constritiva crônica do nervo isquiático de ratos. Para tanto, foi avaliada a sensibilidade dolorosa dos animais utilizando inibidor seletivo para NOS neuronal (nNOS) e induzível (iNOS), antes e após os testes comportamentais. Avaliamos também a distribuição das isoenzimas da NOS, na medula espinal e gânglios da raiz posterior, pelo método de imunohistoquímica. Ainda, separadamente, analisou-se a síntese de nNOS e iNOS, pelo método de Western blot, e a presença de óxido nítrico utilizando marcador fluorescente DAF-2 (DA). Tais investigações poderão contribuir fornecendo base científica para o desenvolvimento de novos medicamentos e por elucidar alguns dos mecanismos de ação do óxido nítrico, envolvidos na dor neuropática, que é de difícil tratamento e de grande relevância clínica.

Palavras-chave: Neuropatia. Lesão constritiva crônica. CCI. Óxido nítrico. NO. 7-NI. LNIL. 


\begin{abstract}
Rocha PA. Effect of Nitric Oxide Synthase in neuropathic pain. [Masters thesis (Morfofunctional Science)] - Institute of Biomedical Sciences of University of São Paulo, São Paulo, 2011.

The peripheral nerve injury results in persistent or chronic neuropathic pain characterized by spontaneous burning pain accompanied by allodynia and hyperalgesia. The occurrence of pathological changes in the peripheral nervous system and spinal cord contributes to the development of neuropathic pain. These changes include ectopic discharges in damaged peripheral nerve fibers, which maintain the afferent nerve impulses to the central nervous system. Many substances synthesized and / or released during inflammation such as neuropeptides, cytokines, nitric oxide, among others, as well as cellular morphofunctional changes, may interfere with the activity of those fibers. These changes in the homeostasis of the individual can result in a loss of quality of life of the patient. Therefore, such information is essential for an effective analgesic therapy and / or preventive. The aims of this project are to better understand the involvement of neuronal and inducible isoforms in a model of neuropathic pain induced by chronic constriction injury in sciatic nerve of rats. We evaluated the pain sensitivity of animals using a selective inhibitor for neuronal (nNOS) and inducible (iNOS) NOS. We also evaluate the distribution of NOS isoenzymes in the spinal cord and dorsal root ganglia, by the method of immunohistochemistry. Separately, we analyzed the synthesis of iNOS and nNOS by Western blot assay, and the presence of nitric oxide using fluorescent probe DAF-2 (DA). Such research could contribute to providing scientific basis for the development of new drugs and to elucidate some of the mechanisms of action of NOS involved in neuropathic pain.
\end{abstract}

Keywords: Neuropathy. Chronic constriction injury. CCI. Nitric oxide. NO. 7-NI. L-NIL. 


\section{LISTA DE ILUSTRAÇÕES}

Figura 1 - Ilustração do modelo de lesão por constrição crônica do nervo isquiático (CCI) 29

Figura 2 - Ilustração do teste de pressão de pata - Randall e Sellito........................................ 31

Figura 3 - Ilustração do teste de hiperalgesia térmica - Hargreaves........................................ 32

Figura 4 - Ilustração do teste de estimulação tátil - filamentos de Von Frey............................ 32

Figura 5 - Efeito da CCI no nervo isquiático sobre o limiar nociceptivo............................... 38

Figura 6 - Efeito da CCI no nervo isquiático sobre a latência de retirada da pata................... 39

Figura 7 - Efeito da CCI no nervo isquiático sobre o limiar de alodinia............................. 40

Figura 8 - Efeito da inibição de nNOS sobre o limiar nociceptivo em ratos com CCI............ 41

Figura 9 - Efeito da inibição de nNOS sobre a latência de retirada da pata em ratos com

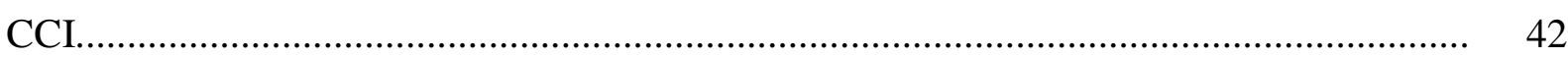

Figura 10 - Efeito da inibição de nNOS sobre o limiar de alodinia em ratos com CCI........... 43

Figura 11 - Efeito da inibição de iNOS sobre o limiar nociceptivo em ratos com CCI........... 44

Figura 12 - Efeito da inibição de iNOS sobre a latência de retirada da pata em ratos com

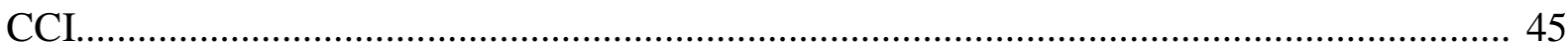

Figura 13 - Efeito da inibição de iNOS sobre o limiar de alodinia em ratos com CCI............ 46

Figura 14 - Fotomicrografias em campo claro de corte imunorreagido para detecção de nNOS da medula espinal - identificação de áreas........................................................... 47

Figura 15 - Fotomicrografias em campo claro de cortes semi-seriados imunorreagidos para detecção de nNOS da medula espinal............................................................................... 48

Figura 16 - Fotomicrografias em campo escuro de cortes semi-seriados imunorreagidos para detecção de iNOS da medula espinal.

Figura 17 - Fotomicrografias em campo escuro de cortes semi-seriados imunorreagidos para detecção de nNOS em DRG.

Figura 18 - Fotomicrografias em campo escuro de cortes semi-seriados imunorreagidos para detecção de iNOS em DRG...................................................................................

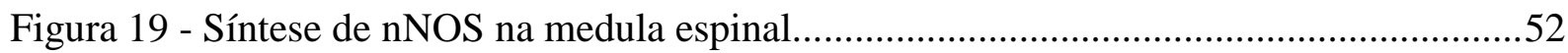

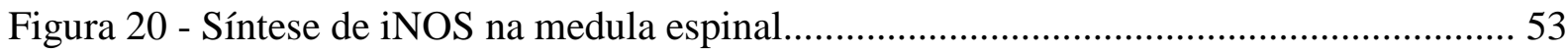

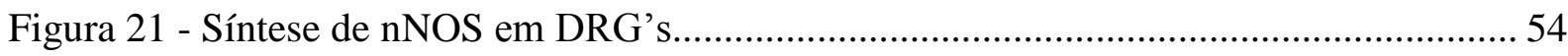

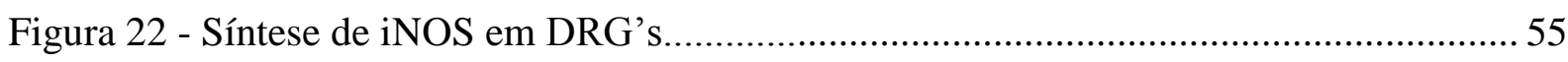

Figura 23 - Reatividade da probe DAF-2 DA em corte transversal da medula espinal......... 56 
Figura 24 - Reatividade da probe DAF-2 DA em corte transversal da medula espinal - in

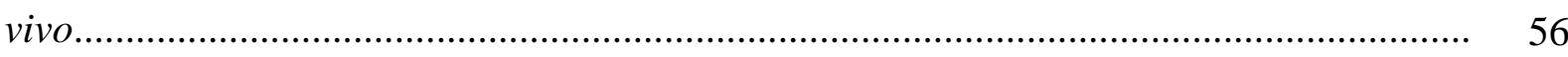

Figura 25 - Reatividade da probe DAF-2 DA em cortes de DRG's...................................... 57 


\section{LISTA DE ABREVIATURAS E SIGLAS}

7-NI - 7-nitroindazol

ARTN - Artemina

ASICs - Canais Iônicos Sensíveis ao Ácido

CC+L-NIL - Lesão Constritiva Crônica + N6-(1-iminoethyl)-L-iysine.dihydrochloride

CCI - Lesão Constritiva Crônica

CCI+7-NI - Lesão Constritiva Crônica + 7-nitroindazol

CCI+veículo - Lesão Constritiva Crônica + veículo de diluição

CGRP - Peptídeo Relacionado ao Gene da Calcitonina

CMHS - Fibras C Térmica e Mecanicamente Sensíveis

c-Ret - Receptor de Neurotrofina

$\mathrm{dH}_{2} \mathrm{O}$ - Água destilada

DRG - Gânglio da Raiz Posterior

EAN - Espécies Ativas de Nitrogênio

EAO - Espécies Ativas de Oxigênio

GDNF - Fator Neurotrófico Derivado de Célula Glial

GFAP - Proteína Glial Fibrilar Ácida

GFLs - Ligantes da Família GDNF 
$\mathrm{H}_{2} \mathrm{O}_{2}$ - Peróxido de Hidrogênio

HTM - Nociceptores Mecânicos de Alto Limiar

IASP - Associação Internacional para o Estudo da Dor

IB4 - Isolectina

iNOS - Óxido Nítrico Sintase induzível

IT - Intratecal

L-NIL - N6-(1-iminoethyl)-L-iysine.dihydrochloride

MF 14d - Medida Final 14 dias após CCI

MF 14d+1h - Medida Final 14 dias após CCI e após uma hora da injeção intratecal

MF 7d - Medida Final sete dias após CCI

MI - Medida Inicial

Mrg - Relacionado ao Gene Mas

NGF - Fator de Crescimento Neural

nNOS - Óxido Nítrico Sintase neuronal

NOS - Óxido Nítrico Sintase

NTN - Neurturina

$\mathrm{O}_{2}^{\bullet-}$ - Ânion Superóxido

$\mathrm{OH}^{\bullet}$ - Radical Hidroxil

$\mathrm{ONOO}^{-}$- Peroxinitrito 
P2X3 - Subtipo de Receptor Purinérgico Específico

PBS - Tampão Fosfato 0,1 M

SNC - Sistema Nervoso Central

SOD - Superoxidodismutase

TRKA - Receptor Tirosina-quinase A

TRPA1 - Receptor de Potencial Transitório Relacionado à Proteína Anquirina 1

TRPM8 - Receptor de Potencial Transitório Melastatina 8

TRPV1 - Receptor de Potencial Transitório Vanilóide 1

VPL - Núcleo Talâmico Ventral Póstero-Lateral

VPM - Núcleo Talâmico Ventral Póstero-Medial 


\section{SUMÁRIO}

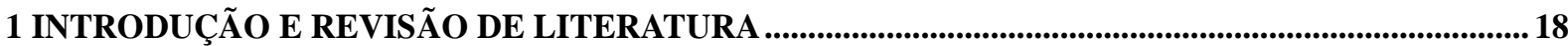

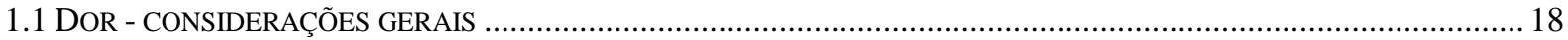

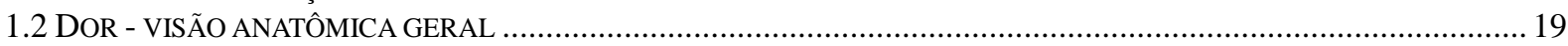

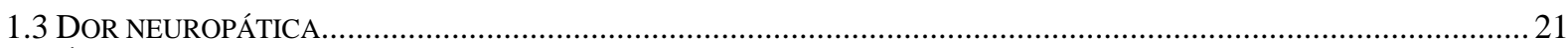

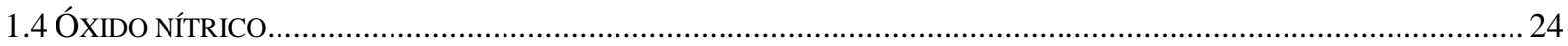

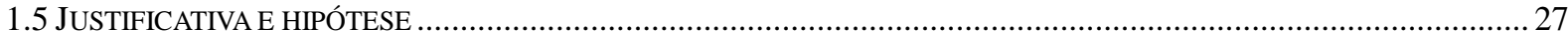

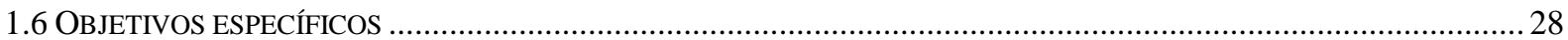

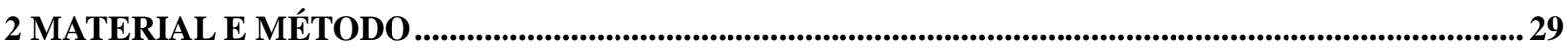

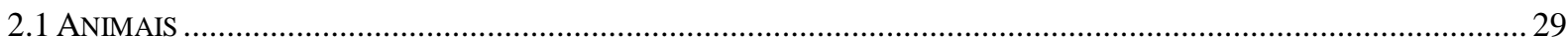

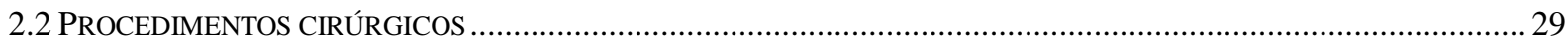

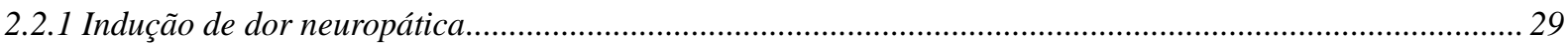

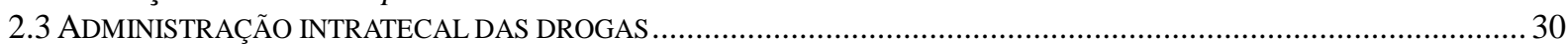

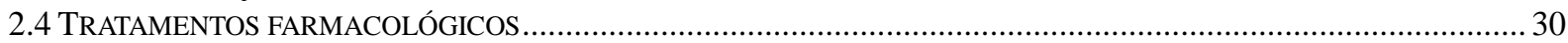

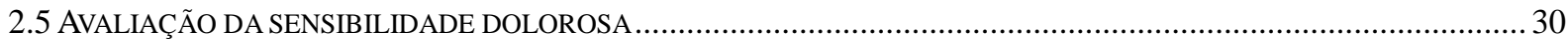

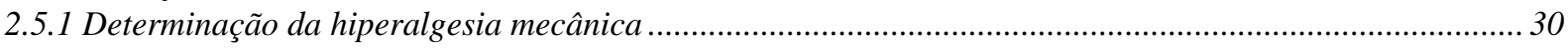

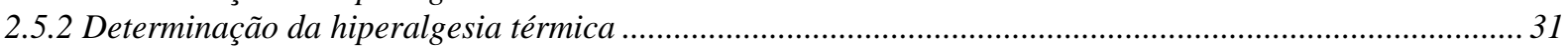

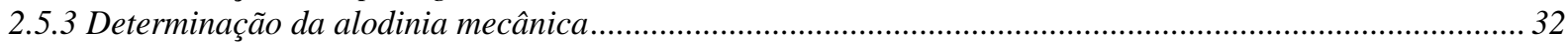

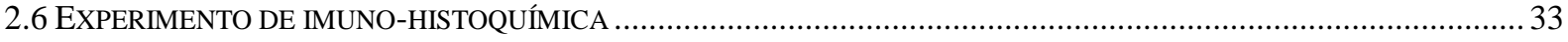

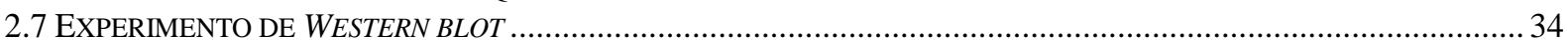

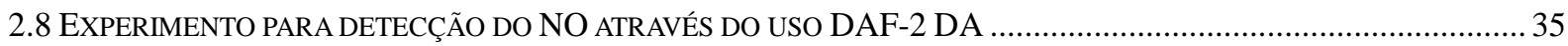

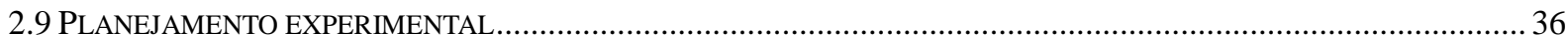

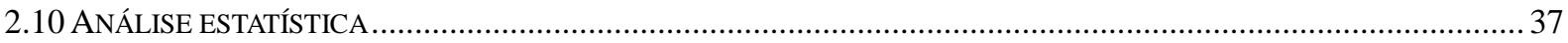

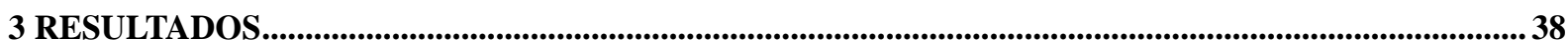

3.1 CARACTERIZAÇÃO DO MODELO EXPERIMENTAL PELO TESTE DE HIPERALGESIA MECÂNICA.................................. 38

3.2 CARACTERIZAÇÃO DO MODELO EXPERIMENTAL PELO TESTE DE HIPERALGESIA TÉRMICA..................................38

3.3 CARACTERIZAÇÃO DO MODELO EXPERIMENTAL PELO TESTE DE ALODINIA MECÂNICA. ...................................... 39

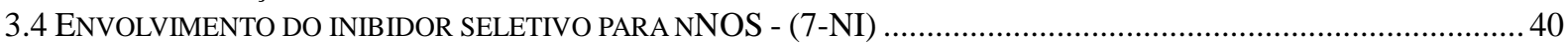

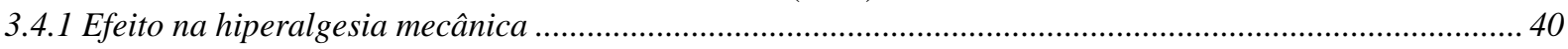

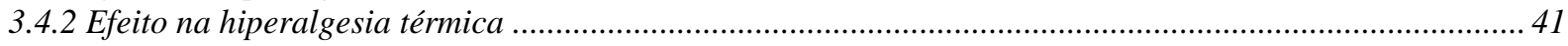

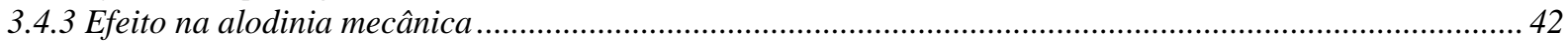

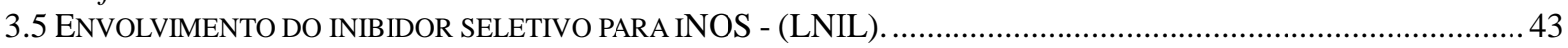

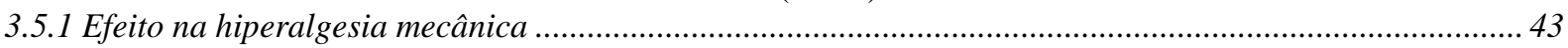

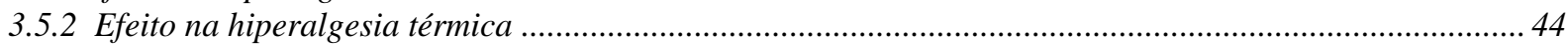

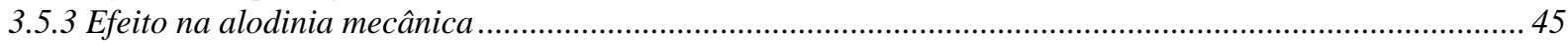

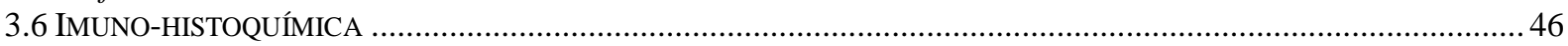

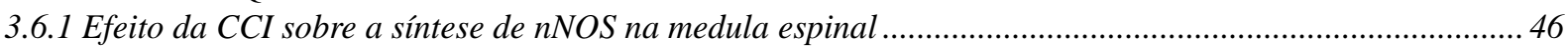

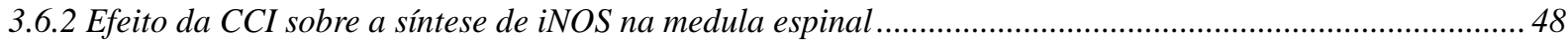

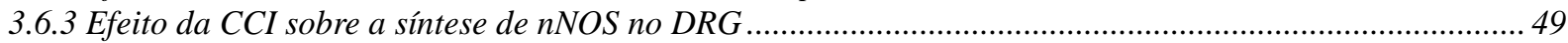

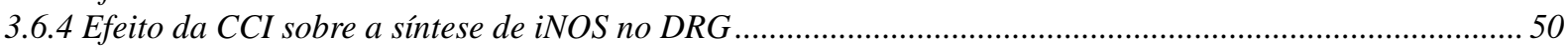

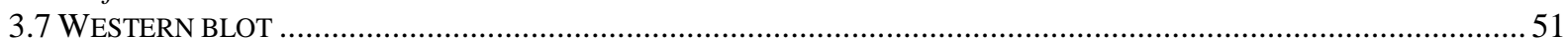

3.7.1 Efeito da CCI sobre a sintese de nNOS na medula espinal ........................................................................52

3.7.2 Efeito da CCI sobre a síntese de iNOS na medula espinal ........................................................................52

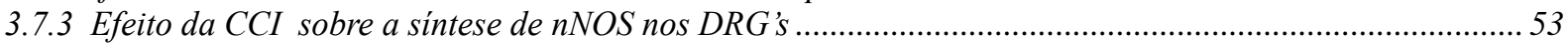

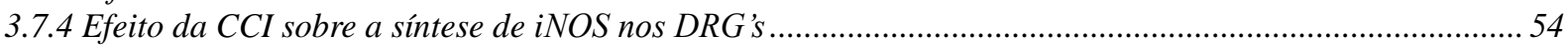

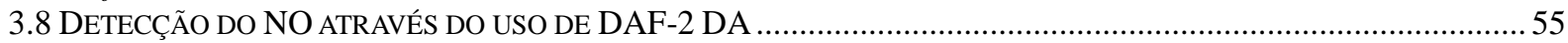

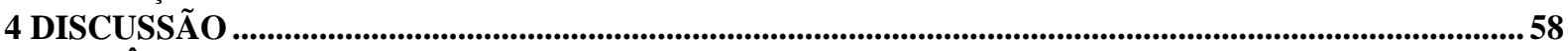

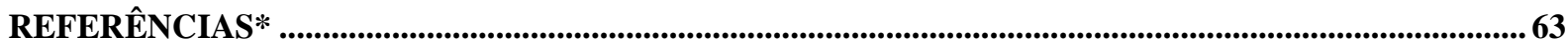




\section{INTRODUÇÃO E REVISÃO DE LITERATURA}

\subsection{Dor - considerações gerais}

A habilidade de detectar estímulos nocivos é essencial para a sobrevivência e bem estar do organismo e por certo período a dor foi concebida apenas "como um dos componentes de um reflexo complexo de proteção do indivíduo", posteriormente, definida pela Associação Internacional para o Estudo da Dor (IASP), que remonta a 1979, aponta para a natureza subjetiva da dor como uma percepção, assim, ajudou a estabelecer a necessidade e o direito do paciente receber tratamento para qualquer tipo de dor. Desde então, é definida como "uma experiência sensorial e emocional desagradável associada a dano tecidual real ou potencial ou descrita em termos de tal dano" ((IASP), 1986; Loeser e Treede, 2008; Melzack e Wall, 1965; Merskey e Kerr, 1979). Portanto, é um processo que envolve sensações e comportamento, cognição, sentimento e memória. Sendo o sentimento, um componente crítico para a experiência dolorosa (Biro, 2010).

A dor pode ser classificada, sob o ponto de vista eminentemente temporal, como aguda, em resposta a estímulos nocivos de alto limiar, sendo assim, considerada uma resposta "fisiológica", um sistema de alerta/proteção ou como crônica, quando em decorrência às alterações e/ou disfunções no sistema somatossensorial, tornando-se debilitante (Basbaum et al., 2009; Julius e Basbaum, 2001). Embora exista a tendência de pensar na dor como uma entidade sensorial homogênea, existem distintos tipos de mecanismos modulatórios envolvidos nesse processamento, e alternativamente, Woolf (2004) propôs a divisão da dor essencialmente em duas grandes categorias: adaptativa e não-adaptativa.

A dor adaptativa é aquela que contribui para a preservação da integridade do organismo pela defesa contra lesão grave e por promover certa proteção à área lesionada. Nessa categoria, encontram-se o a dor do tipo nociceptiva (dor transitória oriunda da ativação dos nociceptores em resposta a um estímulo nocivo) e a dor do tipo inflamatória (dor espontânea e hipersensibilidade dolorosa em resposta ao dano tecidual e a inflamação) considerada também um estado transitório para a categoria da dor não-adaptativa. Essa categoria é a expressão de uma situação patológica do sistema somatossensorial e não está necessariamente ligada ao estímulo nociceptivo evidente ou a uma lesão identificável. Representam essa categoria, a dor neuropática (dor espontânea e hipersensibilidade dolorosa em decorrência a disfunção e/ou lesão no sistema nervoso) e a dor funcional 
(hipersensibilidade dolorosa resultante de processamento central anormal para um input normal) (Loeser e Treede, 2008; Woolf, 2004).

\subsection{Dor - visão anatômica geral}

Há mais de um século Sherrington (1906) propôs a existência de neurônios que possuem terminações nervosas livres de alto limiar (nociceptores) responsáveis pela transmissão da informação nociceptiva (Sherrington, 1906). Segundo este modelo, os nociceptores têm limiares ou sensibilidades característicos que os distinguem de outras fibras nervosas sensoriais.

Estudos eletrofisiológicos têm revelado a existência de neurônios sensoriais primários que podem ser ativados por calor nocivo, pressão intensa ou produtos químicos irritantes, mas não por estímulos inócuos, como o aquecimento ou o toque leve (Burgess e Perl, 1967). Essa subpopulação de fibras nervosa nociceptivas possuem corpos celulares localizados nos gânglios da raiz posterior (DRG’s) que são conjuntos de neurônios sensoriais situados póstero-lateralmente à medula e no gânglio trigêminal, que emitem projeções axônicas tanto para o sistema nervoso central (SNC) quanto para a periferia onde formam arborizações pelos tecidos, por isso são denominados pseudo-unipolares (Basbaum, 2000).

As fibras sensoriais são classificadas em quatro grupos. Fibras A $\alpha$ (Grupo I) são caracterizadas por uma espessa camada de mielina (diâmetro, 12-22 $\mu \mathrm{m}$ ) e uma velocidade de condução rápida $(70-120 \mathrm{~m} / \mathrm{s})$; elas capturam os impulsos aferentes dos fusos neuromusculares e dos órgãos tendinosos de Golgi. Fibras A $\beta$ (Grupo II) têm um fino

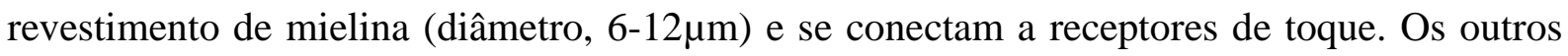
dois grupos de fibras codificam e transmitem principalmente estímulos nociceptivos e térmicos, são as fibras A $\delta$ (Grupo III) que tem a bainha de mielina fina (diâmetro, 1-5 $\mu \mathrm{m}$ ) e velocidade de condução intermediária $(40-30 \mathrm{~m} / \mathrm{s}$ ), e as fibras C (Grupo IV) que são

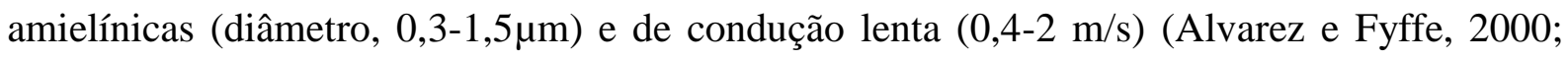
Coggeshall et al., 1983; Julius e Basbaum, 2001).

Tem-se assumido que nociceptores em fibras A $\delta$ e $\mathrm{C}$ medeiam a "primeira" e "segunda" dor, respectivamente, ou seja, a dor rápida, de alerta e aguda, e a dor mais tardia, mais difusa e crônica evocada por estímulos nocivos (Meyer, 2008). Estudos eletrofisiológicos têm subdividido nociceptores $\mathrm{A} \delta$ em duas classes principais: os nociceptores Tipo I (HTM: nociceptores mecânicos de alto limiar) que respondem a estímulos mecânicos e químicos, e têm o limiar para o calor relativamente alto $\left(>50{ }^{\circ} \mathrm{C}\right)$, no entanto, se 
o estímulo de calor é mantido, estes aferentes respondem a temperaturas mais baixas, por sensibilizarem (ou seja, o limiar térmico e/ou mecânico diminui) em decorrência a lesão; e os nociceptores Tipo II tem o limiar de calor muito menor, mas um patamar muito elevado para estímulos mecânicos. A atividade desses aferentes quase certamente medeia a "primeira" resposta ao calor nocivo enquanto os nociceptores Tipo I medeiam provavelmente a "primeira" dor provocada por picada de agulha e outros estímulos mecânicos intensos (Julius e Basbaum, 2001; Meyer, 2008).

As fibras $\mathrm{C}$ também são heterogêneas, a maioria polimodais, isto é, elas incluem uma população térmica e mecanicamente sensíveis (CMHS) e outras que respondem ao calor, mas são mecanicamente insensíveis, (os chamados nociceptores silenciosos), esses desenvolvem sensibilidade mecânica apenas na configuração de lesão, além de serem mais sensíveis a estímulos químicos (capsaicina ou histamina) em relação ao CMHS, provavelmente, são acionados quando as propriedades do meio químico da inflamação se alteram (Perl, 2007; Schmidt et al., 1995). Subconjuntos destes aferentes também são sensíveis a uma variedade de substâncias pruritogenicas. É interessante notar que nem todas as fibras C são nociceptores. Alguns respondem ao resfriamento, e uma população particularmente interessante que respondem às carícias inócuas da pele, mas não ao calor ou a estimulação química, estas parecem mediar o toque agradável (Basbaum et al., 2009; Basbaum et al., 1991; Olausson et al., 2008)

As caracterizações neuroanatômicas e moleculares de nociceptores demonstraram mais uma vez sua heterogeneidade, em particular para as fibras C (Snider e McMahon, 1998). Por exemplo, a chamada população de nociceptores C "peptidérgicos" liberam neuropeptídeos, substância $\mathrm{P}$ e o peptídeo relacionado ao gene da calcitonina (CGRP), e também expressam receptores tirosina-quinase A (TRKA), que respondem a fator de crescimento neural (NGF). A população de nociceptores C "não-peptidérgicos" expressa o receptor de neurotrofina (c-Ret) que é alvo do fator neurotrófico derivado de célula glial (GDNF), bem como da neurturina (NTN) e artemina (ARTN), outros membros de ligantes da família GDNF (GFLs). Uma grande porcentagem da população c-Ret positivas também se liga a isolectina (IB4) e expressa receptores acoplados à proteína G da família Mrg (Dong et al., 2001), bem como subtipos de receptores purinérgicos específicos, particularmente P2X3. Nociceptores também podem ser distinguidos de acordo com sua expressão diferencial de canais que confere sensibilidade ao calor (TRPV1), ao frio (TRPM8), a meios ácidos (ASICs), e uma série de irritantes químicos (TRPA1) (Julius e Basbaum, 2001). Assim, a 
heterogeneidade funcional e molecular de nociceptores associa-se com funções específicas na detecção de distintas modalidades de dor (Basbaum et al., 2009; Julius e Basbaum, 2001).

Existe uma organização laminar muito precisa na coluna posterior da medula espinal. As fibras C "peptidérgicas” e A $\delta$ projetam-se mais superficialmente onde fazem sinapse com neurônios de longa projeção na lâmina I e com interneurônios localizados superiormente na lâmina II. Fibras C “não-peptidérgicas" tem como alvo interneurônios na região inferior da lâmina II. Já, fibras A $\beta$ conectam-se com interneurônios na porção ventral da lâmina II e com neurônios da lamina V onde convergem com projeções de fibras A $\delta$ (Basbaum et al., 2009; Rexed, 1952).

Esses neurônios de segunda ordem ou neurônios de projeção decussam pela comissura branca e inflectem-se cranialmente transmitindo a informação, por diferentes vias ascendentes, para estruturas do tronco encefálico e diencéfalo (Millan, 1999). Dentre as principais projeções supraespinais da via nociceptiva estão os tratos espinomesencefálico, espinoreticular, espino-hipotalâmico e espinotalâmico, sendo este último o mais proeminente na condução do impulso nocivo (Jessell e Kelley, 1991). A via espinotalâmica projeta-se para os núcleos talâmicos específicos, ventral póstero-lateral (VPL) e ventral póstero-medial (VPM), envolvidos com os componentes discriminativos da sensibilidade dolorosa e para os núcleos talâmicos inespecíficos, relacionados com os componentes afetivos da dor.

No tálamo ocorre a recepção, integração e transferência do potencial nociceptivo para o córtex cerebral, onde a informação pode ser somatotopicamente organizada (Craig et al., 1999). Baseando-se em critérios funcionais, as principais regiões corticais envolvidas na resposta dolorosa são os córtices sensorial primário (S-I), secundário (S-II) e motor (ou giro pré-central) (Bromm e Treede, 1987; Schnitzler e Ploner, 2000).

\subsection{Dor neuropática}

Ao contrário da dor nociceptiva, que resulta da ativação fisiológica dos nociceptores por lesão tecidual real ou potencial, a dor neuropática não tem efeito "benéfico" e pode resultar de danos em qualquer ponto do sistema somatosensorial. É classificada como central (provenientes de danos ao cérebro ou à medula espinal) e periférica (provenientes de dano ao nervo periférico, plexo, gânglio da raiz posterior ou raiz dorsal) (Woolf e Mannion, 1999).

De modo geral, os eventos modulatórios da transmissão nociceptiva, e as alterações geradas pela sensibilização central, ocorrem inicialmente na coluna posterior da medula espinal e em núcleos do tronco encefálico e, posteriormente, em centros talâmicos e estruturas 
corticolímbicas. Porém, sob certas condições patológicas como lesão nervosa periférica ou dano ao SNC, a dor pode ser produzida por centros mais superiores, independentemente das terminações periférica (Campbell e Meyer, 2006).

O processamento nociceptivo é mediado por uma grande diversidade de moléculas, dentre elas o glutamato e a substância P que exercem efeitos importantes na iniciação dos mecanismos de sensibilização central. Os neurônios aferentes primários quando estimulados liberam esses mediadores na coluna posterior espinal, ocasionando efeito excitatório nos neurônios de segunda ordem. O glutamato liga-se a diversos tipos de receptores póssinápticos, porém muitos estudos demonstram que a ativação de receptores N-metil-Daspartato (NMDA) mostra-se muito importante na sinalização nociceptiva (Bohme et al., 1993).

O receptor NMDA é um importante canal iônico que permite a passagem de íons cálcio, porém, em estado de inativação, o canal é bloqueado pelo íon magnésio. Com isso para ocorrer ativação do receptor é necessário, além de um agonista, como o glutamato, a presença de uma corrente despolarizante, que remova os íons magnésio promovendo o influxo de cálcio e consequentemente uma despolarização mais intensa da célula pós-sináptica. A geração desta corrente despolarizante ocorre devido ao potencial excitatório gerado pela ligação de substância $\mathrm{P}$ em seus receptores pós-sinápticos, sendo esse mecanismo fundamental para o desbloqueio dos receptores NMDA. Assim pode-se dizer que glutamato e substância $\mathrm{P}$ apresentam efeitos sinérgicos na transmissão nociceptiva na coluna posterior (Bohme et al., 1993; Snyder e Dawson, 1995; Woolf, 2007).

Concomitantemente, o influxo de cálcio resultante da ativação dos receptores NMDA promove a ativação da NOS. O NO produzido atua como mensageiro retrógrado, pois pode difundir-se para neurônios pré-sinápticos da coluna posterior, intensificando a liberação de mediadores pelos terminais dos aferentes primários. Essa condição representa um dos mecanismos de sensibilização central, que resultam em alodinia e hiperalgesia (Coutaux et al., 2005; Woolf, 2007).

Nota-se centralmente também aumento de longa duração da iNOS e NAPH-diaforase, além do aumento dos níveis locais do $\mathrm{TNF} \alpha$, em modelo lesão neuropática a partir do primeiro dia pós-cirúrgico o qual permanece até o vigésimo-oitavo dia. Perifericamente, no segmento distal à lesão do nervo, observa-se aumento significativo de interleucina-1 (IL-1) e interleucina 10 (IL-10), provavelmente mediados também pelos receptores NMDA (George et al., 2005; Kleinschnitz et al., 2005). 
Recentes estudos têm revelado a grande participação glial nos mecanismos nociceptivos. Bem como os neurônios, as células gliais apresentam receptores de glutamato e substância $\mathrm{P}$, sendo assim, também são ativadas em resposta à estimulação dos aferentes primários. Essa ativação determina a liberação de várias substâncias neuroativas que intensificam a sinalização nociceptiva, tais como NO, interleucinas, fatores de crescimento, espécies ativas de oxigênio, prostaglandinas e até mesmo aminoácidos excitatórios. Observou-se também a ativação de cascatas de sinalização intracelular em astrócitos e microglias na medula espinal, envolvendo-se nessas cascatas cinases ativadas por mitógenos (MAPKs), sendo a ativação dessa via correlacionada com a hiperalgesia. Pode-se dizer então que o aumento da sensibilidade dolorosa, que é a expressão do fenômeno de sensibilização central na medula espinal, resulta de circuitos neuronais complexos e também da interação entre neurônios e células gliais (Guo et al., 2008).

Outros fatores importantes envolvidos no processo nociceptivo são o estresse oxidativo e o nitrosativo, que decorrem dos efeitos nocivos das espécies ativas de oxigênio (EAO) e nitrogênio (EAN), efeitos esses que surgem quando as defesas (antioxidantes) apresentam-se reduzidas ou há produção exacerbada em resposta à inflamação periférica, ou, como citado anteriormente, em decorrência à sensibilização central. Dentre as muitas EAO, citam-se o ânion superóxido $\left(\mathrm{O}_{2}^{\bullet-}\right)$, o radical hidroxil $\left(\mathrm{OH}^{\bullet}\right)$ e o peróxido de hidrogênio $\left(\mathrm{H}_{2} \mathrm{O}_{2}\right)$, formadas durante a redução do oxigênio à água. O NO por sua vez, pode se combinar a esse ânion superóxido e formar o peroxinitrito $\left(\mathrm{ONOO}^{-}\right)$, uma $\mathrm{EAN}$ altamente reativa que pode danificar diversos constituintes celulares. Foi demonstrado que após indução de dor inflamatória ocorre aumento na produção de peroxinitrito na periferia e na região correspondente da medula espinal (Wang et al., 2004). A presença do peroxinitrito foi associada à nitração de proteínas, e dentre as proteínas nitradas, foi identificada a superoxidodismutase (SOD), normalmente responsável pela dismutação de ânion superóxido. Assim, a nitração e subsequente inativação da SOD provoca uma maior disponibilidade do ânion superóxido, contribuindo para a formação adicional de peroxinitrito (Finkel e Holbrook, 2000; Fridovich, 1998; Gabbita et al., 2000). Esses eventos mantêm o aumento da excitabilidade dos neurônios de segunda ordem na coluna posterior da medula espinal, o que contribui para a persistência dos sinais nociceptivos. Em maiores instâncias podem levar desde a lesão mitocondrial por peroxidação das membranas, até acumulo de ubiquitina e neurofilamentos por modificação de proteínas e por fim, ativação de vias apoptóticas. Sendo assim, a inibição e/ou regulação da NOS parece ser mais uma vez, uma sugestão indicada para diminuição dos processos nociceptivos e neurodegenerativos (Little et al., 2010). 
Em contrapartida, estudos demonstraram que ratos knockout do gene para iNOS, apresentavam diminuição da regeneração de fibras mielinizadas e retardo na re-inervação do músculo nas placas terminais distais à zona de lesão, demonstrando que a iNOS é um crítico fator na reparação do tecido lesado, além disso, mostra-se super-regulada no tecido inflamado e envolvida no desenvolvimento de hipersensibilidade em modelos de dor inflamatória e dor neuropática (Levy et al., 2001; Sousa e Prado, 2001).

Estes resultados mais uma vez mostram o efeito dual da participação do NO em diferentes processos o que implica a necessidade de melhor esclarecimento da atuação das diferentes enzimas NOS e dos mecanismos de ação desse radical livre em diferentes condições.

\section{4 Óxido nítrico}

O óxido nítrico (NO) é um radical livre gasoso em temperatura ambiental, inorgânico, incolor, que possui cinco elétrons do nitrogênio e seis do oxigênio, tendo um elétron desemparelhado. Apesar de ser uma simples molécula derivada de nitrogênio e oxigênio, desempenhou papel crucial nos primeiros estágios de evolução, quando provavelmente se constituiu um mecanismo de defesa fundamental para microorganismos primitivos, por contrariar a destruição oxidativa, dando-lhes uma vantagem evolutiva (Moncada et al., 1991).

Descoberto no século 17 por Jan B. Helmont e estudado sob o nome de "ar nitroso flogístonizado" por Joseph Priestley, por muitos anos, o NO foi considerado apenas um poluente ambiental. Em 1987, Ignarro, Moncada e outros pesquisadores, identificaram o fator de relaxamento derivado do endotélio (EDRF) como sendo NO. E em 1998, Robert Francis Furchgott, Louis Joseph Ignarro e Ferid Murad, receberam o Prêmio Nobel em Fisiologia ou Medicina, atribuído para "a primeira descoberta de um gás que pode atuar como uma molécula sinalizadora", ressaltando que o NO é um mediador biológico produzido em células de mamíferos.

Posteriormente, extensas pesquisas revelaram que o NO tem um papel importante na maioria dos sistemas de órgãos humanos, na neurotransmissão, na defesa imune, regulação da morte celular e motilidade celular (Beckman e Koppenol, 1996; Morris et al., 1992; Snyder e Dawson, 1995). No início do século 20, o papel do NO foi descoberto na nocicepção tanto a nível central como periférico, investigado em grande parte por Ferreira (1991) e Gebhart (1993), respectivamente (Ferreira et al., 1991; Gebhart, 1993). 
Uma das funções fisiológicas do NO foi inicialmente descoberta na vasculatura, quando foi demonstrado que o papel do EDRF, descrito por Furchgott e Zawadzki, em 1980, podia ser explicado quantitativamente por meio da formação de NO pelas células endoteliais (Furchgott e Zawadzki, 1980). Esse mesmo fator foi relatado como envolvido em mecanismos nociceptivos periféricos por Meller et al., (1990). Moore et al., (1991) também observaram que a L-NG-nitro-arginina (L-NOARG), um inibidor seletivo da biossíntese de NO, exibiu atividade anti-nociceptiva em ratos (Moore et al., 1991). O tratamento da dor com doadores de NO começou com a utilização de nitroglicerina (NTG), um dos mais antigos tratamentos disponíveis para pacientes com doença isquêmica do coração. Embora, NTG tenha sido descoberto em 1847 e utilizado para o alívio da dor na angina do peito por mais de 100 anos, o modo de ação tornou-se claro apenas após o EDRF ter sido identificado como NO (Ignarro et al., 1987).

Foi descoberto, independentemente, que o NO é ativador endógeno da guanilato ciclase solúvel, resultando na formação de GMP cíclico (cGMP), que atua como segundo mensageiro em muitas células, incluindo nervos.

Por ser o nitrogênio e o oxigênio $\left(\mathrm{O}_{2}\right)$ vizinhos na tabela periódica, o NO compartilha varias propriedades com o $\mathrm{O}_{2}$, em particular sua alta afinidade pelo grupo heme e por outros grupos ferro enxofre, sendo importante para a ativação da guanilato ciclase, que contém um grupo heme, e para a inativação do NO pela hemoglobina (Gabbita et al., 2000).

O NO, portanto é um mensageiro químico difusível através das membranas citoplasmáticas, altamente reativo, sendo sua síntese a única forma de regulá-lo, apresenta importante papel no controle da transmissão neuronal, processos inflamatórios, citotoxidade e plasticidade neural. Modula a excitabilidade de neurônios sensoriais espinais e contribui para a dor de diferentes maneiras (Allan e Rothwell, 2003; Garthwaite, 1991; Koeberle e Ball, 1999; Lee et al., 2003; Unger e Lange, 1992; Zembowicz et al., 1991).

O controle da biossíntese de NO é regulado por enzimas NO sintase (NOS). Existem três isoformas conhecidas das NOS: uma forma induzível (expressa nos macrófagos e células de Kupffer, neutrófilos, microglia, fibroblastos, músculo liso vascular e células endoteliais em resposta a estímulos patológicos como organismos invasores) e duas formas ditas constitutivas que estão presentes em condições fisiológicas no endotélio e neurônios. Essas formas são designadas iNOS (ou mNOS ou NOS-II), eNOS (ou ecNOS ou NOS-III) e nNOS (ou ncNOS ou NOS-I), respectivamente (Bredt et al., 1992; Contestabile, 2000; Moncada et al., 1991; Snyder e Dawson, 1995) . 
Essas enzimas são proteínas codificadas por genes distintos em cromossomos diferentes, mas todas elas têm a mesma estrutura genômica, são enzimas diméricas, complexas tanto em nível estrutural como funcional, exibindo semelhança com as enzimas do citocromo P450 que são muito importantes no metabolismo das drogas. Cada isoforma contém ferro protoporfirina IX (heme), flavina adenina-dinucleotídio (FAD), flavina mononucleotídio (FMN) e tetraidrobiopterina como grupos prostéticos ligados. Além disso, contém sítios de ligação para L-arginina, NADPH e cálcio-calmodulina. Esses grupos prostéticos e ligantes controlam a organização da enzima no dímero ativo (Alderton et al., 2001; Dusse et al., 2003).

As enzimas NOS são funcionalmente "bimodais", visto que combinam as atividades de oxigenase e redutase associadas a domínios estruturais distintos. $\mathrm{O}$ domínio da oxigenase contém heme, ao passo que o domínio da redutase liga-se ao cálcio-calmodulina, à FMN, à FAD e ao NADPH. Por analogia com o citocromo P450, acredita-se que as flavinas aceitam elétrons do NADPH e os transferem para o ferro hêmico que se liga ao $\mathrm{O}_{2}$ e catalisa a oxidação em etapas da L-arginina em NO e citrulina. As formas não acopladas da enzima transferem elétrons para outros substratos, como oxigênio molecular, resultando na síntese de ânion superóxido em vez de NO (Alderton et al., 2001).

A atividade das isoformas constitutivas da NOS é controlada pelo cálcio-calmodulina intracelular. Ao contrário dessas, à atividade da iNOS independe da $\left[\mathrm{Ca}^{+}\right]_{\mathrm{i}}$. Apesar de conter um sítio de ligação para o cálcio-calmodulina, a afinidade muito elevada desse sítio pelo seu ligante permite que a iNOS seja ativada até mesmo quando há baixos valores de $\left[\mathrm{Ca}^{+}\right]_{\mathrm{i}}$ observados em condições basais. A indução dessa isoforma, ocorre então, por citocinas e/ou endotoxinas em uma variedade de células. Esta isoforrma requer algumas horas pra ser expressa, mas, uma vez sintetizada, libera quantidades maiores de NO que as formas constitutivas e a produção deste continua indefinidamente até que a L-arginina ou cofatores necessários para sua síntese sejam depletados ou ocorra morte celular. Existe importantes diferenças na inductilidade da iNOS entre espécies, verificando-se indução menos rápida nas células humanas do que nas células de camundongos (Alderton et al., 2001).

Todas as isoformas de NOS podem ser inibidas por análogos da arginina $\mathrm{N}^{3}$-do grupo guanidino substituídos, como a NG-monometil-L-arginina (L-NMMA), N-imino-etilLornitina (L-NIO), NG-amino-L-arginina (L-NAA), NG-nitro- L-arginina (L-NA) e o metil éster correspondente, o NG-nitro-L-arginina-metil-éster (L-Name). Estes análogos competem 
com a L-arginina e agem como inibidores estereoespecíficos da NOS. Além destes inibidores, a 7-nitroindazol (7-NI), dose dependente, e a N6-(1-iminoethyl)-L-iysine.dihydrochloride (LNIL), são capazes de inibir de forma relativamente seletiva a nNOS e iNOS respectivamente. Vários destes inibidores têm sido utilizados em estudos da função do NO, tanto em células isoladas como in vivo (Alderton et al., 2001; Dusse et al., 2003; Guedes, 2007; Moncada e Higgs, 1995; Moncada et al., 1991).

\subsection{Justificativa e hipótese}

Esta proposta está conectada a uma série de investigações realizadas em nosso grupo de pesquisa ao longo dos últimos anos, com o objetivo geral de entender os aspectos da fisiopatologia da dor. Tais processos são estudados em diferentes condições fisiopatológicas como indução de dor neuropática, muscular e aguda. Alternativas terapêuticas para o tratamento da dor neuropática se fazem necessárias, uma vez que essa patologia não responde satisfatoriamente a nenhum tipo de intervenção convencional. Em particular, este projeto visa à melhor compreensão da participação do NO na atividade nociceptiva durante neuropatia crônica, induzida por CCI do nervo isquiático, após inibição da nNOS e iNOS separadamente, bem como a avaliação destes inibidores na distribuição e expressão das isoenzimas e na produção de NO.

Como mencionado anteriormente, as células da glia (astrócitos e microglia), além de participarem de processos inflamatórios, têm papel relevante para a manutenção de processos algogênicos, liberando quantidades elevadas de diferentes mediadores envolvidos na transmissão da informação nociceptiva, incluindo, óxido nítrico (NO). Desta maneira, o objetivo central deste projeto é aprofundar nossa compreensão e explorar em maior detalhe a participação da NOS, mas especificamente da nNOS e iNOS, após a indução de dor neuropática. A hipótese central comum ao conjunto desta proposta é a interação do comportamento animal com as analises dos ensaios de imuno-histoquímica, Western blot e DAF-2(DA). Espera-se que esta série de investigações contribua para maior elucidação dos mecanismos envolvidos na gênese da dor neuropática, pela melhor compreensão dos mecanismos de ação do NO e identificação das isoenzima 


\subsection{Objetivos específicos}

$\checkmark$ Avaliação da sensibilidade dolorosa dos animais após lesão constritiva crônica e após utilização de inibidores específicos para nNOS e iNOS, utilizando modelos de hiperalgesia térmica e mecânica e alodinia;

$\checkmark$ Avaliação da distribuição de nNOS e iNOS, pelo método de imuno-histoquímica, na medula espinal e nos gânglios da raiz posterior, antes e após utilização dos inibidores específicos para as respectivas isoenzimas;

$\checkmark$ Determinação da expressão de nNOS e iNOS, na medula espinal e nos gânglios da raiz posterior, pelo método de Western blot, antes e após a utilização de inibidores específicos para as respectivas isoenzimas;

$\checkmark$ Avaliação dos efeitos da constrição do nervo isquiático sobre a produção do NO, por meio da utilização de indicador fluorescente DAF2-DA, na medula espinal. 


\section{MATERIAL E MÉTODO}

\subsection{Animais}

Foram utilizados ratos machos Wistar, pesando entre 180-220g. Os animais foram mantidos com água e ração ad libitum em uma sala apropriada, com isolamento acústico, temperatura controlada $\left(22{ }^{\circ} \mathrm{C} \pm 1\right)$ e ciclo claro/escuro $(12: 12 \mathrm{~h})$. Todos os procedimentos foram realizados de acordo com o protocolo aprovado pela Comissão de Ética em Experimentação Animal (CEEA) do ICB, protocolo $\mathrm{n}^{0}$ 29, fls 68 livro 02/2009. Para a realização dos experimentos, os animais foram manipulados considerando os princípios e o guia de uso de animais de laboratório envolvendo dor e nocicepção (Zimmermann, 1983).

\subsection{Procedimentos cirúrgicos}

\subsubsection{Indução de dor neuropática}

Para a indução de dor neuropática, foi realizada cirurgia no nervo isquiático, de acordo com o método descrito por Bennett e Xie (1988). Os animais foram anestesiados com Halotano 2,5\% (Cristália- Brasil) com fluxo contínuo de oxigênio (5 L/min). O músculo bíceps femoral foi rebatido e o nervo exposto na região mediana da coxa. A aproximadamente $7 \mathrm{~mm}$ de distância da trifurcação do nervo isquiático foram realizadas 4 ligaduras frouxas ao redor deste, distantes entre si em aproximadamente $1 \mathrm{~mm}$, com fio de sutura categute cromado 4-0. A incisão foi suturada em camadas, utilizando fio de sutura de seda número 4-0 (Figura 1). O grupo controle foi dividido em dois, sendo um composto por animais falso-operados (Sham), submetidos à mesma incisão que os animais operados, com a exposição do nervo isquiático, porém sem ligaduras ao redor do nervo e outro grupo por animais sem nenhum procedimento cirúrgico (naive) (Bennett e Xie, 1988).

Figura 1 - Ilustração do modelo de lesão por constrição crônica do nervo isquiático (CCI)

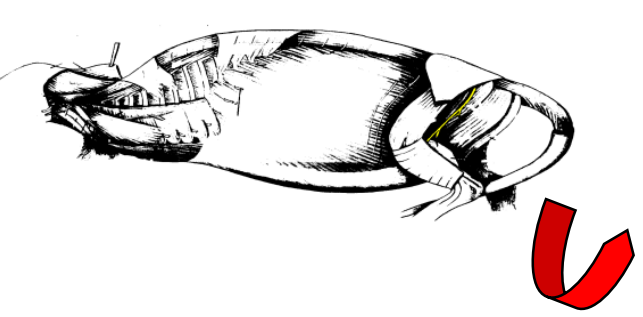

FONTE: Modificado de Bennett e Xie (1988).

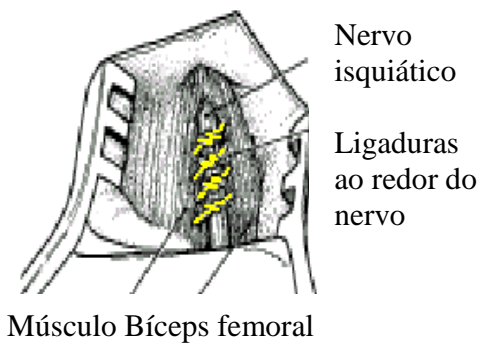

Músculo Bíceps femoral 


\subsection{Administração intratecal das drogas}

Para injeções intratecais, utilizamos o método de acordo com o proposto por Milligan et al., (2004). Os animais foram anestesiados com Halotano 2,5\% (Cristália- Brasil) com fluxo contínuo de oxigênio ( $5 \mathrm{~L} / \mathrm{min}$ ) em posição de decúbito dorsal. Erguendo-se o osso ilíaco (espinhas ilíacas ventrais), uma agulha de número $18 \mathrm{G}$ (40 x 12) foi inserida diretamente no espaço subaracnóideo entre as vértebras lombares L5 e L6. Imediatamente após a inserção, o flick (retirada da cauda) característico, foi observado, indicando a entrada da agulha no espaço subaracnóideo da medula e em seguida o fármaco no volume de $50 \mu \mathrm{L}$ foi liberado (Milligan et al., 2004).

\subsection{Tratamentos farmacológicos}

Com o intuito de avaliar o envolvimento da nNOS e iNOS na hipernocicepção induzida por constrição do nervo isquiático, foram utilizados inibidores seletivos de ambas isoenzimas, sendo o 7-nitroindazol (7-NI, Sigma-Aldrich, USA), inibidor da enzima nNOS na concentração de $1.11 \mu \mathrm{M}(0,0014 \mathrm{ug} / \mathrm{rato} / 50 \mathrm{ul})$. (Babbedge et al., 1993) e o L-iminoetil-lisina (L-NIL, Sigma-Aldrich, USA), inibidor seletivo da enzima iNOS na concentração de $1.11 \mu \mathrm{M}$ (0,0009ug/rato/50ul), ambos dissolvidos em água deionizada e administrado por via intratecal no $14^{\circ}$ dia pós-cirurgia. Uma hora após a administração intratecal dos fármacos, os animais foram novamente submetidos ao teste para hiperalgesia e ao teste para alodinia. Após o término do comportamento, os animais foram divididos em dois grupos, ensaios de imunohistoquímica e ensaios de immunoblotting. Nos grupo controle utilizamos o veículo de diluíção. As doses escolhidas foram baseadas em trabalhos descritos na literatura (Chacur et al., 2010; Osborne e Coderre, 1999)

\subsection{Avaliação da sensibilidade dolorosa}

\subsubsection{Determinação da hiperalgesia mecânica}

Para a avaliação da sensibilidade dolorosa dos animais foi utilizado o teste de pressão da pata de ratos (Analgesy-Meter Ugo Basile, Itália), realizado de acordo com o método descrito por Randall e Sellito (1957) (Figura 2). Neste teste, uma força em gramas (g), de magnitude crescente (16 g/s), é continuamente aplicada sobre o dorso da pata experimental do 
animal e interrompida quando esse apresenta a reação de "retirada" do membro. Neste modelo, o limiar de dor é representado como a força (g) necessária para a indução da reação (Randall e Selitto, 1957).

Este teste e os outros explicados a seguir foram aplicados antes do procedimento cirúrgico (MI), no $14^{\circ}$ dia após a lesão (MF14d) e uma hora após os diferentes tratamentos farmacológicos ou controle $(\mathrm{MF} 14 \mathrm{~d}+1 \mathrm{~h})$. Os resultados foram analisados através da comparação das médias das medidas iniciais e finais, e pela comparação das médias obtidas entre os diferentes grupos experimentais.

Figura 2 - Ilustração do teste de pressão de pata - Randall e Sellito

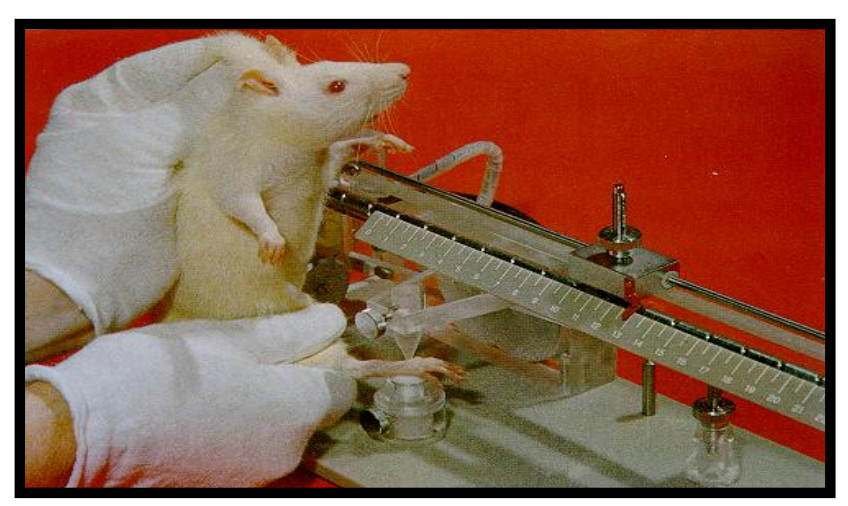

FONTE: Laboratório de Neuroanatomia Funcional Dor. Departamento de Anatomia. Instituto de Ciências Biomédicas da Universidade de São Paulo (USP).

\subsubsection{Determinação da hiperalgesia térmica}

A determinação da hiperalgesia térmica foi feita por meio do teste descrito por Hargreaves (Hargreaves et al., 1988), conforme ilustrado na figura três. O animal é colocado em compartimento de acrílico sobre uma plataforma de vidro própria que permite a passagem da luz e do calor de forma homogênea. Sob a plataforma, uma fonte de luz infravermelha está acoplada a um monitor que registra em segundos o limiar térmico do animal. Após ser posicionada, a fonte é acionada e emite um feixe de luz de incidência constante sob a região plantar da pata experimental do animal até apresente o comportamento de retirada da pata ou até que o aquecimento atinja o limite de tempo predeterminado (tempo de corte de 30" para evitar lesão). 
Figura 3 - Ilustração do teste de hiperalgesia térmica - Hargreaves

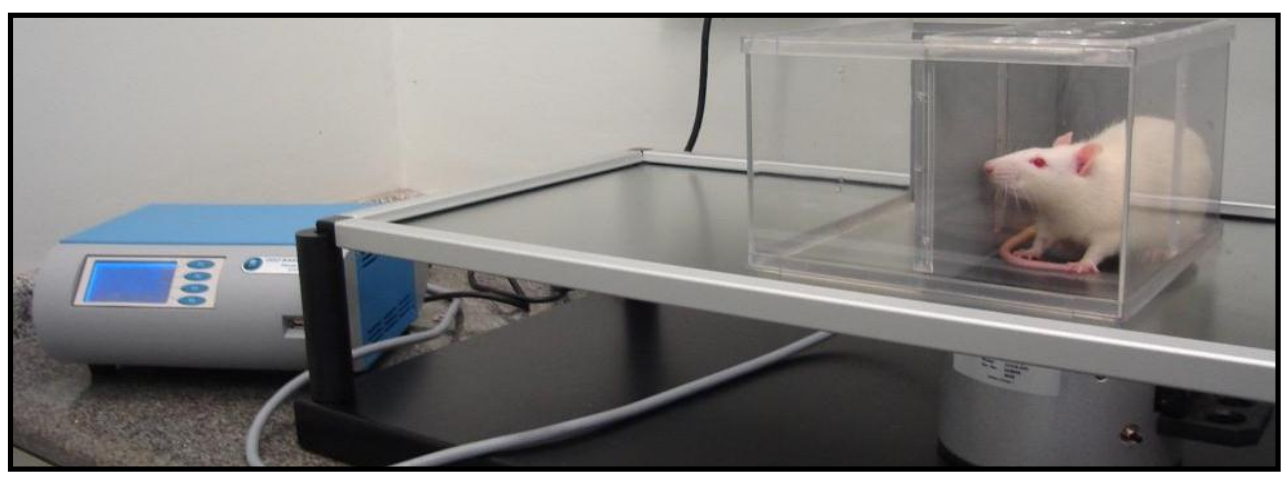

FONTE: Laboratório de Neuroanatomia Funcional Dor. Departamento de Anatomia. Instituto de Ciências Biomédicas da Universidade de São Paulo (USP).

\subsubsection{Determinação da alodinia mecânica}

A determinação da alodinia mecânica foi avaliada por ensaio quantitativo, em resposta a estímulo tátil aplicado à região plantar da pata experimental do animal, segundo método descrito por Chaplan (1994), modificado. Neste teste, o animal é mantido em recipiente de acrílico sobre plataforma de arame, o que permitir o acesso à pata experimental. Os animais foram habituados, por uma hora, durante os dois dias que antecederam os experimentos (Chaplan et al., 1994), e por 10 minutos antes do início do experimento. Para o ensaio de alodinia, foi empregada uma série logarítmica de 10 filamentos de Von Frey (Aesthesiometer Semmes-Weinstein, Stoelting Co., EUA) (Figura 3). Os filamentos e seus valores respectivos em gramas são: 3.61 (0.407 g.); 3.84 (0.692g.); 4.08 (1.202 g.); 4.17 (1.479 g.); 4.31 (2.041 g.); 4.56 (3.630 g.); 4.74 (5.495 g.); 4.93 (8.511 g.); 5.07(11.749 g) e 5.18 (15.136 g.). O filamento capaz de induzir a retirada da pata, duas vezes consecutivas, foi considerado como a força em gramas necessária para induzir a resposta (100\% de resposta).

Figura 4 - Ilustração do teste de estimulação tátil- filamentos de Von Frey

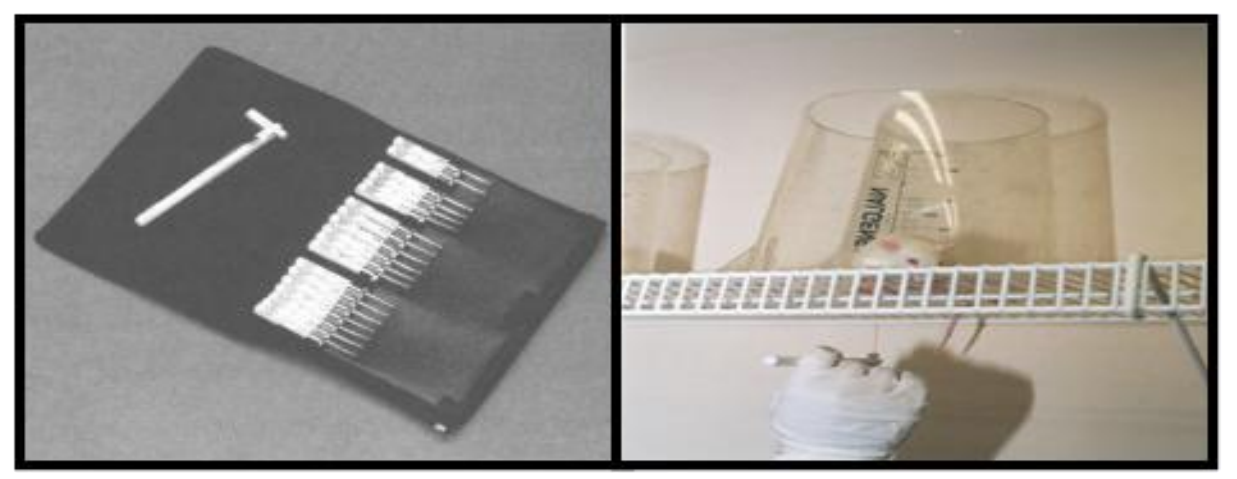

FONTE: Laboratório de Neuroanatomia Funcional Dor. Departamento de Anatomia. Instituto de Ciências Biomédicas da Universidade de São Paulo (USP). 
Inicialmente os animais foram avaliados nos testes para hiperalgesia e em seguida submetidos ao teste para alodinia, ou seja, foram utilizados os mesmo animais em todos os testes comportamentais.

\subsection{Experimento de imuno-histoquímica}

Para realização deste ensaio, 14 dias após a lesão constritiva crônica e/ou após os tratamentos farmacológicos, os animais foram anestesiados e submetidos à perfusão transcardíaca, com solução salina $(300 \mathrm{ml})$, seguida de solução fixadora $(500 \mathrm{ml})$ constituída de formaldeído $4 \%$ em tampão fosfato $0,1 \mathrm{M}$ (PBS, pH 7,4). Após perfusão, a intumescência lombossacral (L6-L3) da medula espinal e o DRG's, referentes à mesma porção, foram coletados e armazenados em formaldeído 4\%, durante 4 horas. Após este período, o material foi transferido para solução de sacarose $30 \%$, para crioproteção.

As medulas foram cortadas à espessura de $30 \mu \mathrm{m}$ em micrótomo deslizante de congelamento e os gânglios cortados à espessura de $12 \mu \mathrm{m}$ em criostato mantido à $-30{ }^{\circ} \mathrm{C}$.

Os cortes da medula foram coletados em placas para cultura seis poços contendo solução PBS $0,1 \mathrm{M}$ e submetidos à metodologia de imuno-histoquímica free-floating nas seguintes etapas: a) incubação com anticorpo primário, overnight (16h) em roller rotator à temperatura ambiente para detecção de epítopo específico das enzimas nNOS, monoclonal mouse anti-nNOS [1:1000] (Sigma, St. Louis, MO, USA) e iNOS (monoclonal mouse antiiNOS [1:200] - BD Science, USA) ambos diluídos em solução PBS 0,1M com triton X-100 $0,3 \%$, contendo $50 \mu \mathrm{L}$ de soro normal de cabra (NGS), volume final da solução igual a um ml; b) três lavagens de $10^{\prime}$ cada com PBS $0,1 \mathrm{M}$; c) incubação sob agitação, durante 2 horas à temperatura ambiente, com anticorpo secundário biotinilado (Biotin-SP-Goat Anti-Mouse IgG $(\mathrm{H}+\mathrm{L})$ [1:200] - Jackson ImmunoResearch, EUA) e secundário de florescência com espectro de emissão na faixa do verde (FITC-Goat Anti-Mouse IgG (H+L) [1:100] - Jackson ImmunoResearch, EUA), respectivamente, diluídos em solução PBS 0,1M com triton X-100 $0,3 \%$, volume final igual a um $\mathrm{ml}$; d) três lavagens de 10' cada com PBS 0,1M . As próximas etapas referem-se apenas a reação com secundário biotinilado: e) amplificação da marcação com complexo avidina-biotina-peroxidase (ABC Kit, Vector Laboratories, EUA) em solução PBS 0,1M com triton X-100 0,3\%, durante uma hora e 30’ f) precipitação do cromógeno DAB (3,3'-diaminobenzidina - Sigma-Aldrich, EUA) na peroxidase utilizando solução de peróxido de hidrogênio $0,01 \%$ em PBS 0,1M. 
Os cortes reagidos com DAB foram montados em lâminas, com meio de montagem a base de glicerol, e os cortes reagidos para imunofluorescência, montados em lâmina com PBS $0,1 \mathrm{M}$, ambos mantidos em placa quente a $32^{\circ} \mathrm{C}$, no caso da fluorescência protegidos da luz, por no mínimo duas horas. As lâminas reagidas com DAB passaram por bateria de desidratação e foram cobertas com lamínula utilizando Permount Mounting Medium (Fisher Scientific, USA), e as lâminas para fluorescência cobertas com lamínula utilizando Vectashield Mounting Medium (Vector Laboratories, USA). A imunorreatividade foi analisada ao microscópio de luz e ao microscópio Nikon Eclipse 80i equipado com epifluorescência e uma câmera digital Nikon DXM 1200F.

Os cortes do gânglio foram coletados em lâmina (6 séries) e as lâminas mantidas por no mínimo duas horas em placa quente a $32{ }^{\circ} \mathrm{C}$. Posteriormente, submetidas à metodologia de imunofluorescência para detecção de epítopo específicos das enzimas nNOS e iNOS. As etapas da reação e os anticorpos primários correspondem ao descrito anteriormente, o que difere é o anticorpo secundário de fluorescência que nesse caso tem espectro de emissão na faixa do vermelho (TRITC-Goat Anti-Mouse IgG (H+L) [1:100] - Jackson ImmunoResearch, EUA). Além disso, ao final da reação, os cortes foram incubados com traçador neuronal que tem espectro de emissão na faixa do verde (NeuroTrance [1:1000] - Invitrogen,EUA) em PBS $0,1 \mathrm{M}$ por 30', sendo assim, uma dupla-marcação. As lâminas foram cobertas com lamínula utilizando Vectashield Mounting Medium (Vector Laboratories, USA). A imunorreatividade foi analisada ao microscópio Nikon Eclipse 80i equipado com epifluorescência e uma câmera digital Nikon DXM 1200F.

\subsection{Experimento de Western blot}

A intumescência lombossacral (L6-L3) da medula espinal e os gânglios da raiz posterior (L6-L3) dos diferentes grupos experimentais, após decepção dos animais, foram rapidamente coletados e congelados em nitrogênio líquido. Cabe mencionar que foram coletados e processados separadamente os lados ipsilateral e contralateral da medula espinal e dos gânglios da raiz posterior. Além disso, foi feito um "pool" com os quatro gânglios de cada lado de dois animais do mesmo grupo experimental no total de oito gânglios por amostra, para alcançar uma quantidade suficiente de proteína.

A extração das proteínas foi realizada com tampão de extração a frio e homogeneizado a 19000rpm com Polytron (Kinematica AG, Suiça), após essa etapa foi adicionado ao homogenato $10 \%$ do volume do tampão de extração de tritron X-100 10\% e mantido em gelo 
por 30'. A separação foi realizada em centrifuga a $4{ }^{\circ} \mathrm{C}, 12000 \mathrm{rpm}$, por $20^{\prime}$. O conteúdo proteico total do sobrenadante isolado foi dosado pelo método de Bradford (Amresco, USA) (Bradford, 1976). Após essa quantificação, os materiais foram diluídos em um mesmo volume de tampão Laemmli (Bio-Rad, USA), contendo 0,01mg/ml de DTT (Sigma, USA), as amostras foram posteriormente fervidas em banho maria por 5 min e o material foi aplicado em gel de poliacrilamida $6,5 \%$ e submetido a eletroforese com corrente contínua de $120 \mathrm{~V}$.

Após a separação eletroforética, as proteínas foram transferidas para uma membrana de nitrocelulose (Millipore, $0,2 \mu \mathrm{m}$ de diâmetro) de acordo com a técnica descrita por Towbin et al., (1979). Os antígenos presentes na membrana de nitrocelulose foram submetidos à caracterização imunoenzimática. Após bloqueio com leite desnatado (Molico, Nestlé) 5\% em tampão Tris-Salina (Tris $10 \mathrm{mM}$ e $\mathrm{NaCl} 0,15 \mathrm{M}, \mathrm{pH}$ 7,5), por 2 horas, as membranas foram lavadas com Tris-Salina e incubadas com anticorpos para o reconhecimento de epítopo específico das enzimas nNOS (monoclonal mouse anti-nNOS [1:500] - Sigma, St. Louis, MO, USA) e iNOS (monoclonal mouse anti-iNOS [1:200] - BD Science, USA) em solução bloqueadora ( $1 \%$ de BSA) por 18 horas a $4{ }^{\circ} \mathrm{C}$. Em seguida, as membranas foram lavadas com Tris-Salina e incubadas por 2 horas com o anticorpo secundário conjugado com peroxidase de raiz forte (1:3000 Amershan Biosciences, NJ/EUA). O excesso foi removido com mais de um ciclo de lavagens com Tris-Salina. A $\beta$-actina foi utilizada como controle interno da reação (monoclonal mouse anti- $\beta$-actina [1:10000] - Sigma, USA). As membranas foram reveladas utilizando o Kit ECL (Amershan Biosciences, NJ/EUA) de quimiluminescência e foram analisadas quanto à densidade óptica das bandas, com o programa Scion Image (Scion Corporation, Frederick, MD/EUA). A análise dos dados foi feita pela média das diferenças percentuais entre os diferentes grupos experimentais.

\subsection{Experimento para detecção do NO através do uso DAF-2 DA}

Duas metodologias foram realizadas para detecção do NO presente na intumescência lombossacral (L6-L4) da medula espinal e nos gânglios da raiz posterior referentes à mesma porção. A primeira metodologia realizada foi baseada no método descrito por Mabuchi et al., (2003), os animais foram anestesiados com tribromoethanol 2,5\% (1ml/100g), a porção lombossacral e os gânglios da raiz posterior foram retirados e imediatamente transferidos para fluido cefalorraquidiano artificial (ACSF) equilibrado com carbogênio (95\% de $\mathrm{O}_{2}$ e 5\% de $\mathrm{CO}_{2}$ ), as meninges foram retiradas e o tecido embebido em Agar low-melting 3\% diluído em ACSF, o material foi cortado em vibrátomo a espessura de $160 \mu \mathrm{m}$, os cortes coletados foram 
transferidos para ACSF equilibrado com carbogênio e mantidos por 30min para estabilização, após, transferidos para ACSF contendo $5 \mu \mathrm{M}$ de 4-5 diacetato de diaminofluoresceína (DAF-2; Alexis Biochemicals, San Diego, CA) por 45' em temperatura ambiente, o material foi lavado em ACSF por 30min e fixado em formaldeído 4\% por 30'. Em seguida o tecido foi examinado em microscópio de fluorescência, a análise dos dados foi feita através da comparação da intensidade de fluorescência entre os lados ipsilateral e contralateral, e entre os animais dos diferentes grupos. As imagens digitais foram obtidas por meio de uma câmera digital acoplada ao microscópio.

A segunda metodologia foi baseada no método descrito por Torrão e Britto (2004), os tecidos foram coletados igualmente ao descrito anteriormente, porém, as meninges não foram retiradas e os gânglios da raiz posterior foram mantidos unidos à medula. Rapidamente o tecido foi emblocado em um recipiente contendo tissue-freeze e mergulhado em isopentanol e gelo seco, posteriormente cortado em criostato em fatias de $20 \mu \mathrm{m}$ de espessura e os cortes coletados em lâminas gelatinizadas, mantidas em placa quente por 30min. As lâminas foram umedecidas com PBS $0,1 \mathrm{M}$ por $30^{\prime}$. Adicionou-se $5 \mu \mathrm{M}$ de $4-5$ diacetato de diaminofluoresceína (DAF-2; Alexis Biochemicals, San Diego, CA) em PBS contendo $0,5 \mathrm{mM}$ de cloreto de cálcio por uma hora a $37^{\circ} \mathrm{C}$. Após esse período o material foi examinado em um microscópio de fluorescência. A análise foi realizada pela comparação visual entre animais experimentais e controle, com ou sem inibidores da NOS, observando-se a intensidade da fluorescência. As imagens foram analisadas ao microscópio Nikon Eclipse 80i equipado com epifluorescência e uma câmera digital Nikon DXM 1200F (Torrão e Britto, 2004).

\subsection{Planejamento experimental}

Para a caracterização da lesão constritiva crônica do nervo isquiático e dos diferentes tratamentos farmacológicos os animais foram divididos conforme os grupos experimentais descritos abaixo, sendo $\mathrm{n}=5$ para imuno-histoquímica, $\mathrm{n}=5$ para Western blot e $\mathrm{n}=6$ para detecção do NO com DAF-2DA. Todos os animais foram inicialmente submetidos aos testes comportamentais e a seguir submetidos aos diferentes ensaios, totalizando, 112 ratos.

- Grupo 1: ratos com dor neuropática (CCI), sacrificados 14 dias após procedimento, subdividido em:

a) Grupo 1a: ratos com CCI e inibidor seletivo da nNOS por via I.T., n=16;

b) Grupo 1b: ratos com CCI e inibidor seletivo da iNOS por via I.T., $n=16$; 
c) Grupo 1c: ratos com CCI e veículo de diluição por via I.T., n=16;

- Grupo 2: ratos controle - falso operado (Sham), sacrificados 14 dia após procedimento, subdividido em:

a) Grupo 2a: ratos controle - Sham e inibidor seletivo da nNOS por via I.T., n=16;

b) Grupo 2b: ratos controle - Sham e inibidor seletivo da iNOS por via I.T., $n=16$;

c) Grupo 2c: ratos controle - Sham e veículo de diluição por via I.T., n=16;

- Grupo 3: ratos controle - naive, $\mathrm{n}=16$

O grupo 1c foi realizado para descartar a possibilidade do veículo de diluição per se estar interferindo com o resultado. O mesmo para os grupos ( 2 a e b) em relação aos inibidores.

\subsection{Análise estatística}

Nos testes comportamentais avaliou-se a variância entre grupos e dentro dos grupos realizando uma Análise de Variância (ANOVA) de medidas repetidas, seguida de teste Post Hoc Bonferroni. O índice de significância considerado foi de $\mathrm{p} \leq 0,05$. Intervalo de confiança de 95\%. Nas analises de Western blot, os dados foram representados como média \pm e.p.m. A comparação estatística entre os grupos foi realizada usando a análise de variância de uma via (ANOVA), seguido pelo teste de Turkey. O índice de significância considerado foi de $\mathrm{p} \leq 0,05$. A análise estatística foi gerada utilizando o programa GraphPad Prism 5 (GraphPad Software Inc., CA, USA). 


\section{RESULTADOS}

\subsection{Caracterização do modelo experimental pelo teste de hiperalgesia mecânica.}

Os animais sem sofrer nenhum procedimento cirúrgico, foram submetidos ao teste comportamental para hiperalgesia mecânica descrito por Randall e Selitto. Após essa medida inicial (MI), conforme a divisão dos grupos, os animais sofreram as respectivas intervenções. No décimo quarto dia após a lesão, todos os animais foram reavaliados para verificação de possíveis alterações do limiar nociceptivo, medido em gramas.

Foi observada diminuição do limiar nociceptivo dos animais com CCI quando comparado com o grupo controle (naive e Sham), demonstrando o efeito hiperalgésico do procedimento cirúrgico.

Figura 5 - Efeito da CCI no nervo isquiático sobre o limiar nociceptivo

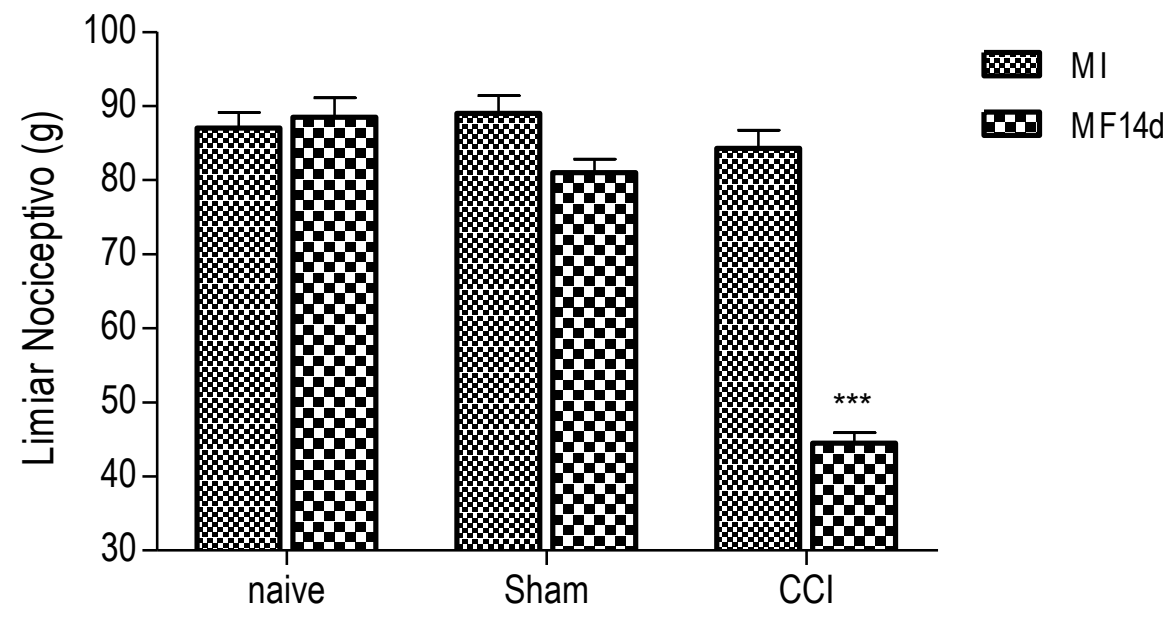

Avaliado pelo teste de Randall \& Selitto, expresso em gramas, determinado em diferentes tempos, sendo eles, medida inicial (MI) e no $14^{\circ}$ dia após a lesão (M14d). Uma ANOVA de medidas repetidas foi executada $(\mathrm{F}(2,47)$ $=50,91 \mathrm{com} p<0,001)$; um tamanho de efeito global de $0,684\left(\eta^{2}\right.$ parcial) mostrou que aproximadamente $68 \%$ da variação nas medidas podem ser creditadas as diferenças dos grupos. Para naive $\mathrm{n}=10$ e para os outros grupos $\mathrm{n}=20$. ***em comparação à MI dentro do grupo e entre os grupos.

FONTE: Laboratório de Neuroanatomia Funcional Dor. Departamento de Anatomia. Instituto de Ciências Biomédicas da Universidade de São Paulo (USP).

\subsection{Caracterização do modelo experimental pelo teste de hiperalgesia térmica.}

Este teste comportamental consiste em avaliar a sensibilidade térmica dos animais na resposta dolorosa. Como descrito anteriormente, o teste comportamental foi realizado nos animais antes do procedimento cirúrgico, medida inicial (MI) e 14 dias pós-lesão (M14d). Foi observada diminuição significativa do grupo CCI em relação aos grupos controles, Sham e 
naive (Figura 6) Não foi possível observar diferença estatística entre os grupos controles (Sham e Naive).

As alterações observadas referem-se à diminuição do limiar térmico ocasionado pela sensibilização central decorrente da CCI.

Figura 6 - Efeito da CCI no nervo isquiático sobre a latência de retirada da pata

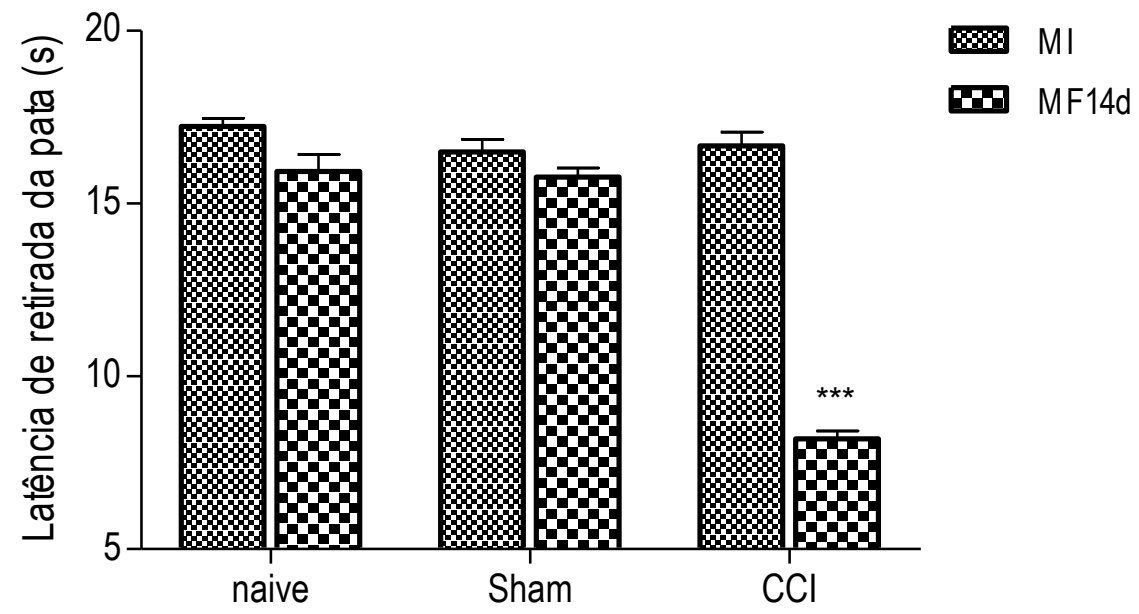

Avaliada pelo teste de Hargreaves, expresso em segundos, determinado em diferentes tempos, sendo eles, medida inicial (MI) e no $14^{\circ}$ dias após a lesão (M14d). Uma ANOVA de medidas repetidas foi executada $(\mathrm{F}(2,39)=67,83 \mathrm{com} \mathrm{p}<0,001)$; um tamanho de efeito global de 0,777 ( $\eta^{2}$ parcial) mostrou que aproximadamente $78 \%$ da variação nas medidas podem ser creditadas as diferenças dos grupos. Para todos os grupos $\mathrm{n}=14$. ***em comparação à MI dentro do grupo e entre os grupos.

FONTE: Laboratório de Neuroanatomia Funcional Dor. Departamento de Anatomia. Instituto de Ciências Biomédicas da Universidade de São Paulo (USP).

\subsection{Caracterização do modelo experimental pelo teste de alodinia mecânica.}

Esse teste consiste na verificação da percepção à dor em resposta a estímulo tátil, ou seja, estímulo não doloroso.

Foi observada diminuição no limiar do grupo com CCI após 14 dias de lesão, quando comparado com os grupos controles (Naive e Sham). Esta diminuição do limiar determina a manifestação de alodinia, comum em neuropatias. 
Figura 7 - Efeito da CCI no nervo isquiático sobre o limiar de alodinia

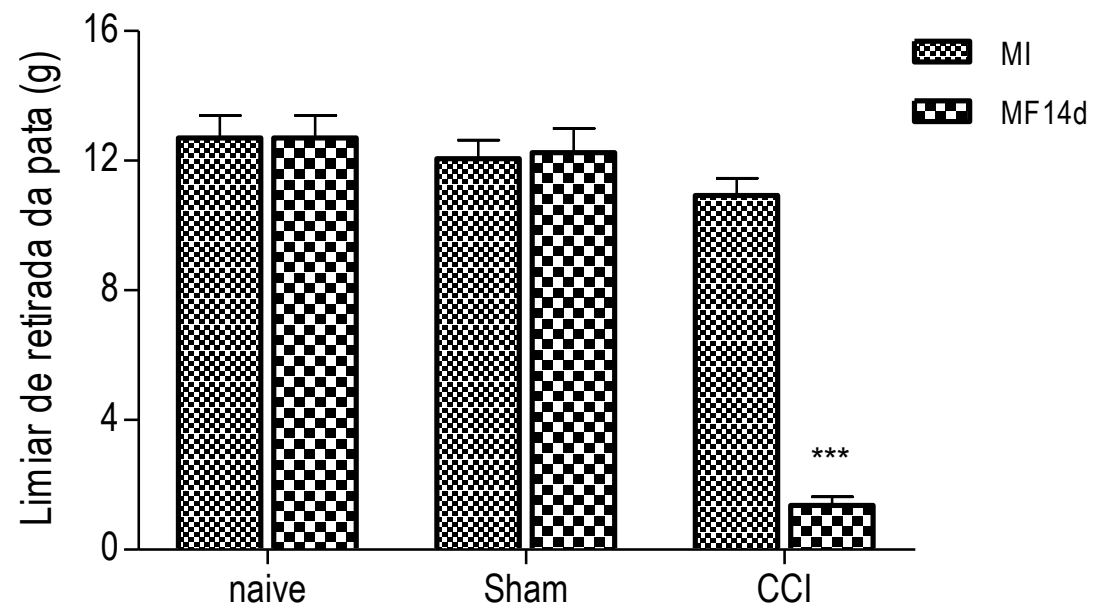

Avaliada pelo teste de filamentos de von Frey, expresso em gramas, determinado em diferentes tempos, sendo eles, medida inicial (MI) e no $14^{\circ}$ dias após a lesão (M14d). Uma ANOVA de medidas repetidas foi executada $(\mathrm{F}(2,47)=123,80$ com $\mathrm{p}<0,001)$; um tamanho de efeito global de 0,840 ( $\eta^{2}$ parcial) mostrou que aproximadamente $84 \%$ da variação nas medidas podem ser creditadas as diferenças dos grupos. Para naive $\mathrm{n}=10$ e os outros grupos $n=20$. *em comparação à MI dentro do grupo e entre os grupos.

FONTE: Laboratório de Neuroanatomia Funcional Dor. Departamento de Anatomia. Instituto de Ciências Biomédicas da Universidade de São Paulo (USP).

\subsection{Envolvimento do inibidor seletivo para nNOS - (7-NI)}

\subsubsection{Efeito na hiperalgesia mecânica}

O tratamento com 7-NI, inibidor seletivo de nNOS, foi administrado no $14^{\circ}$ dia após a CCI por via i.t. e uma hora após a injeção os animais foram novamente submetidos ao teste de Randall e Selitto. A inibição desta isoforma foi capaz de reverter parcialmente o efeito hiperalgésico da dor neuropática, induzida pela CCI (figura 8). Esta resposta foi apenas parcial uma vez que foi possível observar ainda, significância entre a medida após inibição do grupo com CCI (M14d+1h) e as medidas MI dentro e entre os grupos e as medidas M14d+1h dos diferentes grupos.

Para controle foi utilizado o veículo de diluição, administrado por via i.t.. Como esperado, não se observou significância em relação às medidas nos grupos com $\mathrm{dH} 2 \mathrm{O}$ injetada quando comparadas aos diferentes grupos, excluindo assim a possibilidade do veículo de diluição apresentar efeito analgésico. 
Figura 8 - Efeito da inibição de nNOS sobre o limiar nociceptivo em ratos com CCI

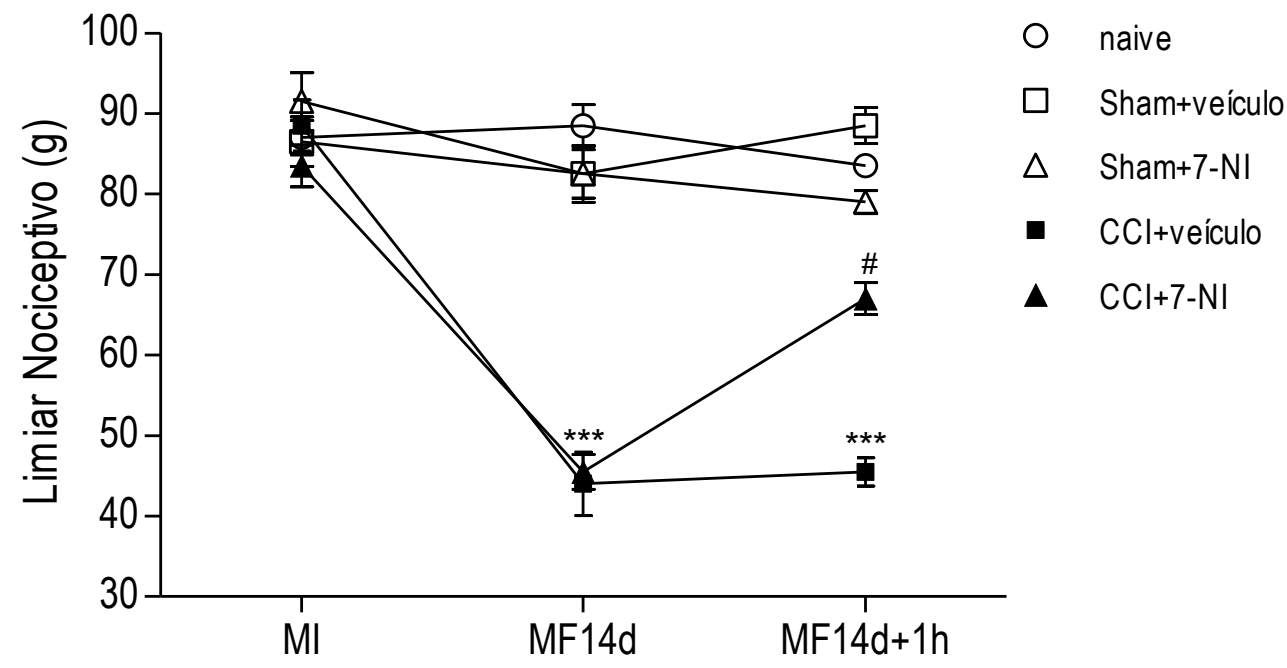

Avaliado pelo teste de Randall e Selitto, expresso em gramas, determinados em diferentes tempos, sendo eles, medida inicial (MI), no $14^{\circ}$ dia após a lesão (M14d) e uma hora após os respectivos tratamentos (M14d+1h). Uma ANOVA de medidas repetidas foi executada $(\mathrm{F}(7,81)=22,04 \mathrm{com} \mathrm{p}<0,001)$; um tamanho de efeito global de $0,662\left(\eta^{2}\right.$ parcial $)$ mostrou que aproximadamente $66 \%$ da variação nas medidas podem ser creditadas aos diversos tratamentos nos diferentes grupos. Para todos os grupos $n=10$. ***em comparação à MI dentro do grupo e entre os grupos, \# em comparação à MI e M14d+1h dentro do grupo e entre grupos.

FONTE: Laboratório de Neuroanatomia Funcional Dor. Departamento de Anatomia. Instituto de Ciências Biomédicas da Universidade de São Paulo (USP).

\subsubsection{Efeito na hiperalgesia térmica}

No $14^{\circ}$ dia após os diferentes procedimentos todos os animais foram reavaliados para verificação de possíveis alterações do limiar térmico, medido em segundos. A inibição da isoforma neuronal, no $14^{\circ}$ dia pós-lesão, avaliada pelo teste de hiperalgesia térmica, se mostrou eficiente. Foi possível observar reversão da hipersensibilidade nos animais com CCI (M14d+1h) após a injeção em comparação à M14d dentro do grupo e entre os diferentes grupos. 
Figura 9 - Efeito da inibição de nNOS sobre a latência de retirada da pata em ratos com CCI

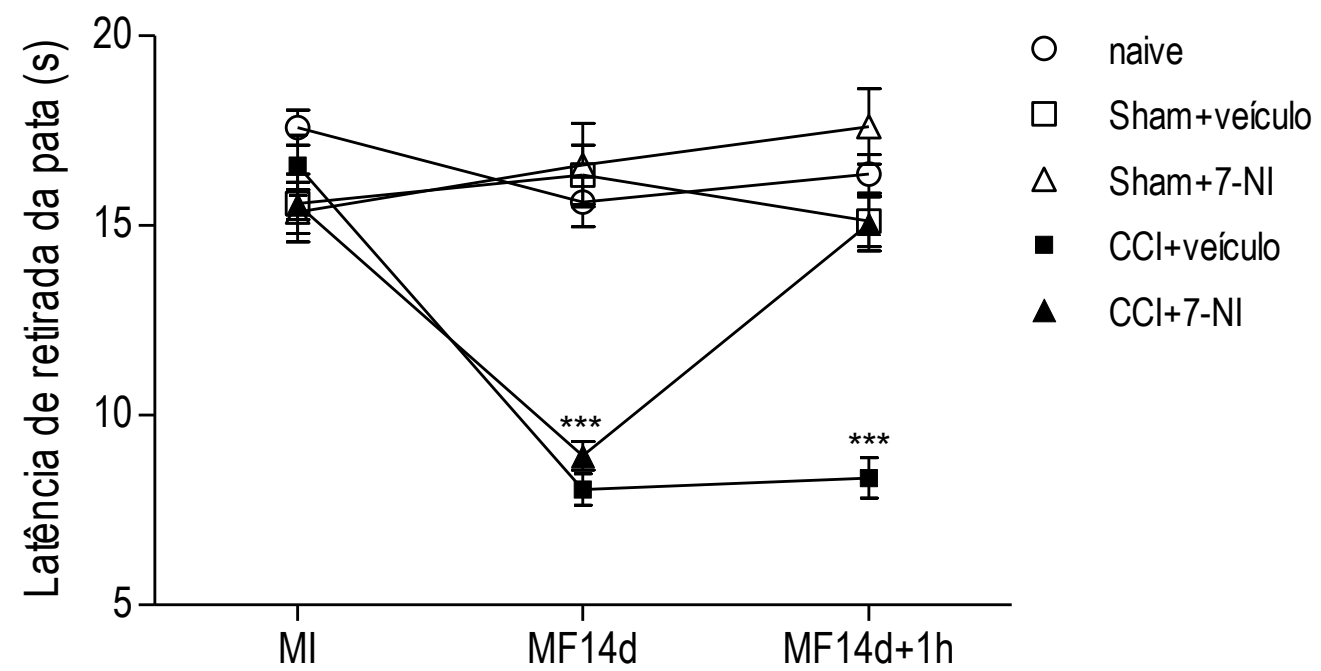

Avaliada pelo teste de Hargreaves, expresso em segundos, determinados em diferentes tempos, sendo eles, medida inicial (MI), no $14^{\circ}$ dia após a lesão (M14d) e uma hora após os respectivos tratamentos $(\mathrm{M} 14 \mathrm{~d}+1 \mathrm{~h})$. Uma ANOVA de medidas repetidas foi executada $(\mathrm{F}(6,52)=17,75$ com $\mathrm{p}<0,001)$; um tamanho de efeito global de 0,703 ( $\eta^{2}$ parcial) mostrou que aproximadamente $70 \%$ da variação nas medidas podem ser creditadas aos diversos tratamentos nos diferentes grupos. Para todos os grupos $\mathrm{n}=7$. ***em comparação à MI dentro do grupo e entre os grupos.

FONTE: Laboratório de Neuroanatomia Funcional Dor. Departamento de Anatomia. Instituto de Ciências Biomédicas da Universidade de São Paulo (USP).

\subsubsection{Efeito na alodinia mecânica}

Após a medida inicial (MI), conforme a divisão dos grupos, os animais sofreram as respectivas intervenções e no décimo quarto dia após os procedimentos, todos os animais foram reavaliados para verificação de possíveis alterações do limiar em resposta ao estímulo tátil. Foi observado reversão total da resposta alodínica após o tratamento como o inibidor 7NI, demostrando a possível participação da nNOS nos processos alodínicos. 
Figura 10 - Efeito da inibição de nNOS sobre o limiar de alodinia em ratos com CCI

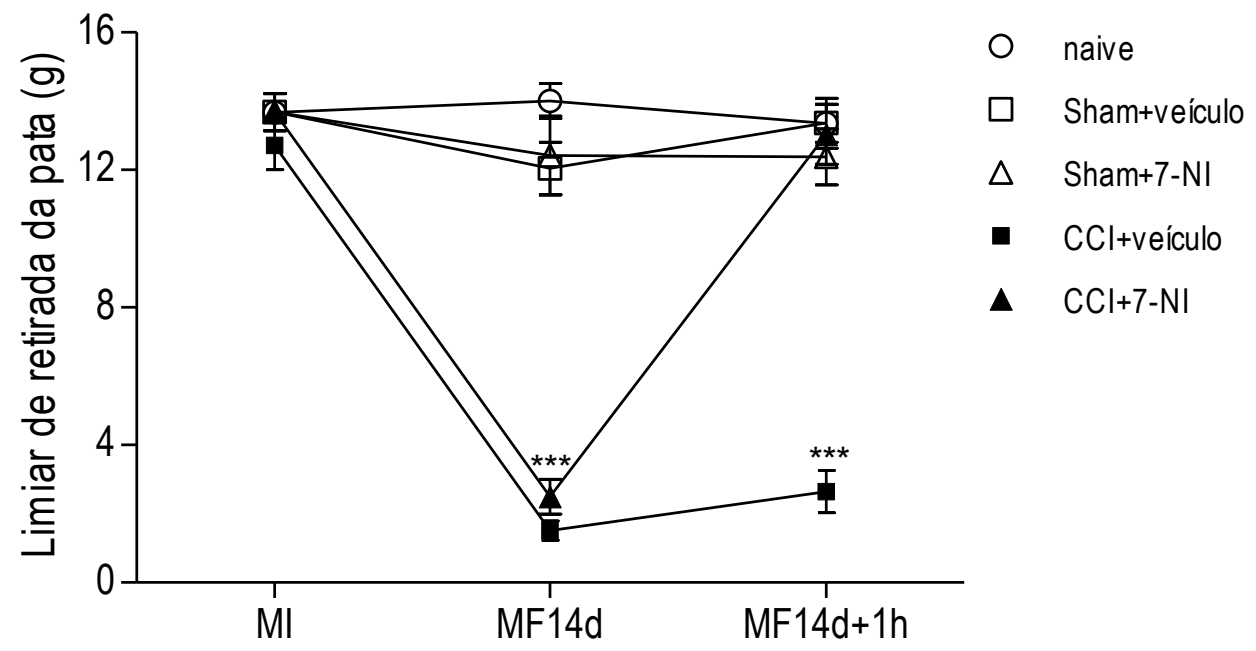

Avaliada pelo teste de filamentos de von Frey, expresso em gramas, determinados em diferentes tempos, sendo eles, medida inicial (MI), no $14^{\circ}$ dia após a lesão (M14d) e uma hora após os respectivos tratamentos $(\mathrm{M} 14 \mathrm{~d}+1 \mathrm{~h})$. Uma ANOVA de medidas repetidas foi executada $(\mathrm{F}(7,84)=46,96 \mathrm{com} \mathrm{p}<0,001)$; um tamanho de efeito global de 0,807 ( $\eta^{2}$ parcial) mostrou que aproximadamente $81 \%$ da variação nas medidas podem ser creditadas aos diversos tratamentos nos diferentes grupos. Para todos os grupos $n=10$. ***em comparação à MI dentro do grupo e entre os grupos, M14d e M14d+1h entre os grupos.

FONTE: Laboratório de Neuroanatomia Funcional Dor. Departamento de Anatomia. Instituto de Ciências Biomédicas da Universidade de São Paulo (USP).

\subsection{Envolvimento do inibidor seletivo para iNOS - (LNIL).}

\subsubsection{Efeito na hiperalgesia mecânica}

O tratamento com L-NIL, no $14^{\circ}$ dia pós-lesão, quando administrado por via i.t., uma hora antes dos testes de Randall e Selitto, foi capaz de reverter parcialmente o efeito hiperalgésico da dor neuropática, quando comparado com o mesmo grupo antes da inibição. 
Figura 11 - Efeito da inibição de iNOS sobre o limiar nociceptivo em ratos com CCI

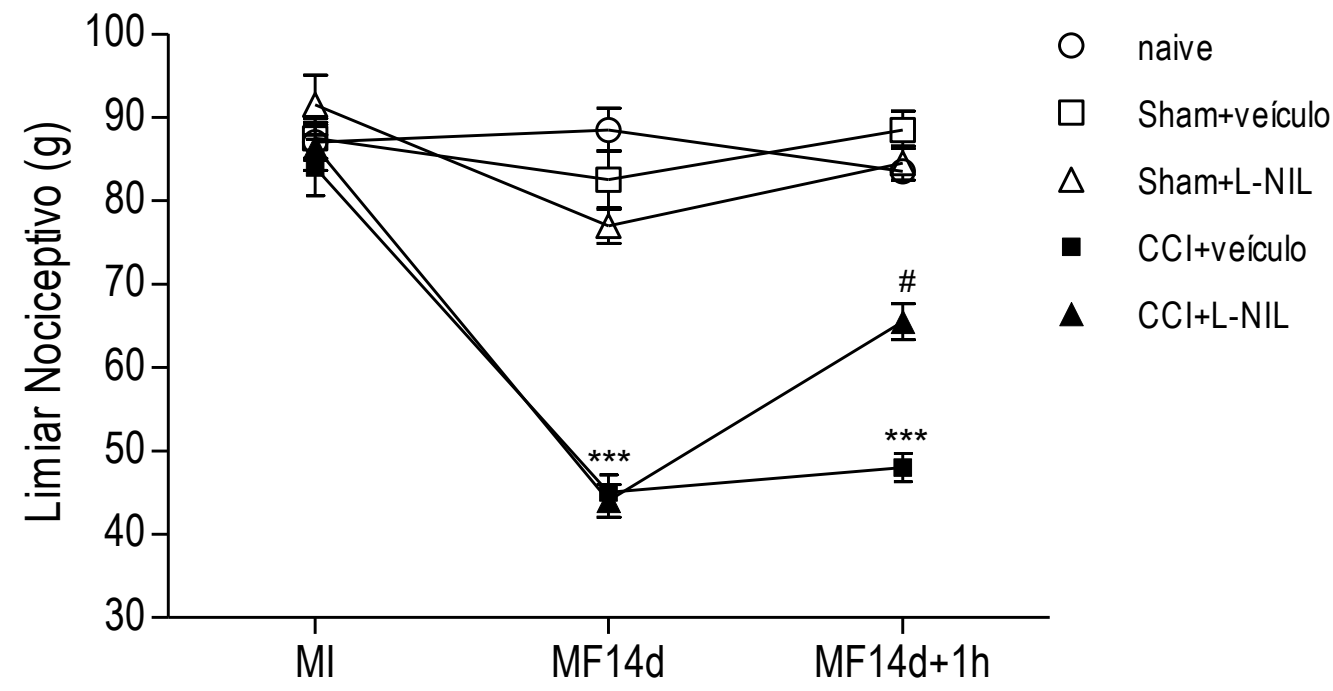

Avaliado pelo teste de Randall e Selitto, expresso em gramas, determinados em diferentes tempos, sendo eles, medida inicial (MI), no $14^{\circ}$ dia após a lesão (M14d) e uma hora após os respectivos tratamentos (M14d+1h). Uma ANOVA de medidas repetidas foi executada $(\mathrm{F}(6,72)=20,48$ com $\mathrm{p}<0,001)$; um tamanho de efeito global de $0,645\left(\eta^{2}\right.$ parcial) mostrou que aproximadamente $64 \%$ da variação nas medidas podem ser creditadas aos diversos tratamentos nos diferentes grupos. Para todos os grupos $n=10$. ***em comparação à MI dentro do grupo e entre os grupos, \# em comparação à MI e M14d+1h dentro do grupo e entre grupos.

FONTE: Laboratório de Neuroanatomia Funcional Dor. Departamento de Anatomia. Instituto de Ciências Biomédicas da Universidade de São Paulo (USP).

\subsubsection{Efeito na hiperalgesia térmica}

A inibição da isoforma induzível, no $14^{\circ}$ dia pós-lesão, avaliada pelo teste de hiperalgesia térmica, se mostrou eficiente. Foi possível observar reversão da hipersensibilidade nos animais com CCI (M14d+1h) após a injeção em comparação à M14d dentro do grupo e entre os diferentes grupos. 
Figura 12 - Efeito da inibição de iNOS sobre a latência de retirada da pata em ratos com CCI

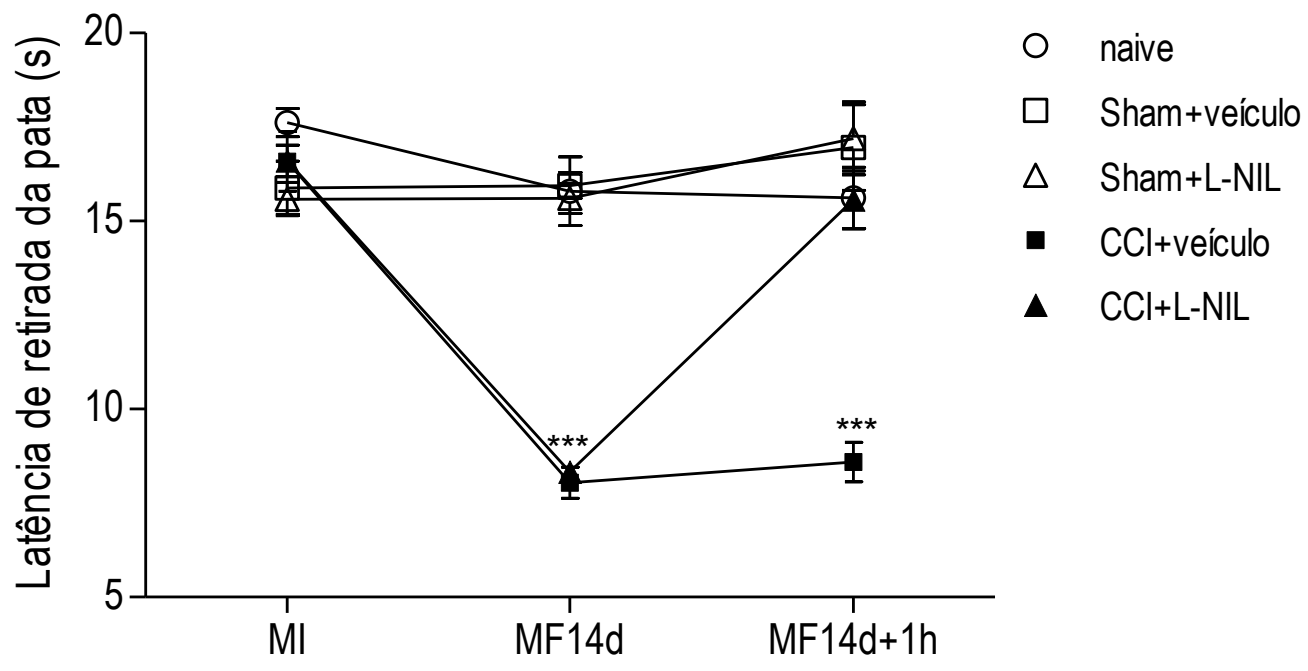

Avaliada pelo teste de Hargreaves, expresso em segundos, determinados em diferentes tempos, sendo eles, medida inicial (MI), no $14^{\circ}$ dia após a lesão (M14d) e uma hora após os respectivos tratamentos (M14d+1h). Uma ANOVA de medidas repetidas foi executada $(\mathrm{F}(7,55)=15,45 \mathrm{com} \mathrm{p}<0,001)$; um tamanho de efeito global de $0,673\left(\eta^{2}\right.$ parcial) mostrou que aproximadamente $67 \%$ da variação nas medidas podem ser creditadas aos diversos tratamentos nos diferentes grupos. Para todos os grupos $\mathrm{n}=7$. ***em comparação à MI dentro do grupo e entre os grupos, M14d e M14d+1h entre os grupos.

FONTE: Laboratório de Neuroanatomia Funcional Dor. Departamento de Anatomia. Instituto de Ciências Biomédicas da Universidade de São Paulo (USP).

\subsubsection{Efeito na alodinia mecânica}

Os animais após o testes comportamentais para hiperalgesia, mencionados anteriormente, foram submetidos ao teste para alodinia mecânica com os filamentos de von Frey. Não foi possível observar alteração significativa no grupo tratado com o inibidor $(\mathrm{M} 14 \mathrm{~d}+1 \mathrm{~h})$ quando comparado ao mesmo grupo antes de receber o tratamento (M14d). 
Figura 13 - Efeito da inibição de iNOS sobre o limiar de alodinia em ratos com CCI

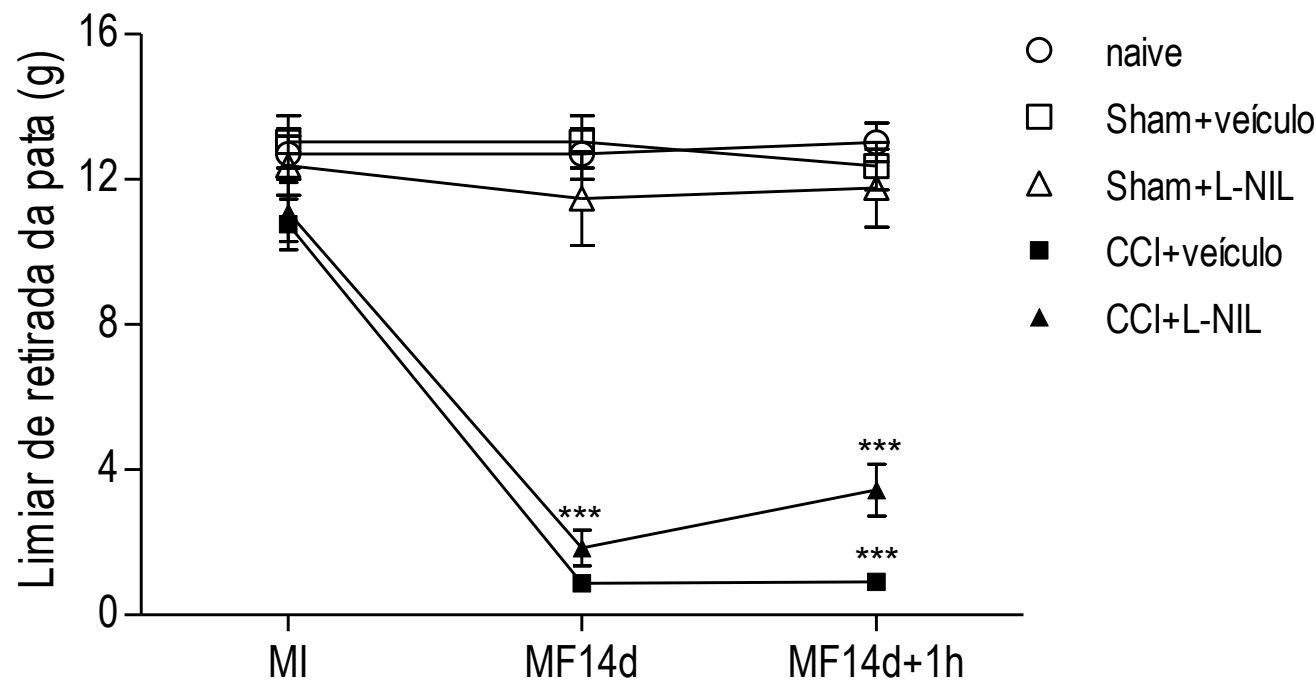

Avaliada pelo teste de filamentos de VonFrey, expresso em gramas, determinados em diferentes tempos, sendo eles, medida inicial (MI), no $14^{\circ}$ dia após a lesão (M14d) e uma hora após os respectivos tratamentos $(\mathrm{M} 14 \mathrm{~d}+1 \mathrm{~h})$. Uma ANOVA de medidas repetidas foi executada $(\mathrm{F}(7,80)=36,00 \mathrm{com} \mathrm{p}<0,001)$; um tamanho de efeito global de $0,762\left(\eta^{2}\right.$ parcial) mostrou que aproximadamente $76 \%$ da variação nas medidas podem ser creditadas aos diversos tratamentos nos diferentes grupos. Para todos os grupos $\mathrm{n}=10$. ***em comparação à MI dentro do grupo e entre os grupos e M14d entre os grupos.

FONTE: Laboratório de Neuroanatomia Funcional Dor. Departamento de Anatomia. Instituto de Ciências Biomédicas da Universidade de São Paulo (USP).

\subsection{Imuno-histoquímica}

\subsubsection{Efeito da CCI sobre a síntese de nNOS na medula espinal}

A enzima nNOS mostrou-se expressa em neurônios da coluna posterior (lâminas I-III) e ao redor do canal central (lâmina X) da medula espinal. O lado direito, ipsilateral à CCI, foi considerado como experimental. A comparação foi feita entre os lados ipsilateral e contralateral, e entre os diferentes grupos (Figura 14).

Nossos resultados demonstraram menor imunorreatividade para nNOS nos grupos experimentais tratados com o inibidor quando comparados aos grupos CCI que receberam o veículo de diluição, em ambos os locais analisados. O mesmo pode ser observado nas fotomicrografias (Figura 15) onde é possível observar essa diminuição do número de células marcadas quando os animais foram tratados com 7-NI e também a semelhança desse grupo com os grupos controle. Ainda, nota-se, uma pequena síntese basal desta isoforma, principalmente, ao redor do canal central. 
Figura 14 - Fotomicrografia em campo claro de corte imunorreagido para detecção de nNOS na medula espinal - identificação das áreas.

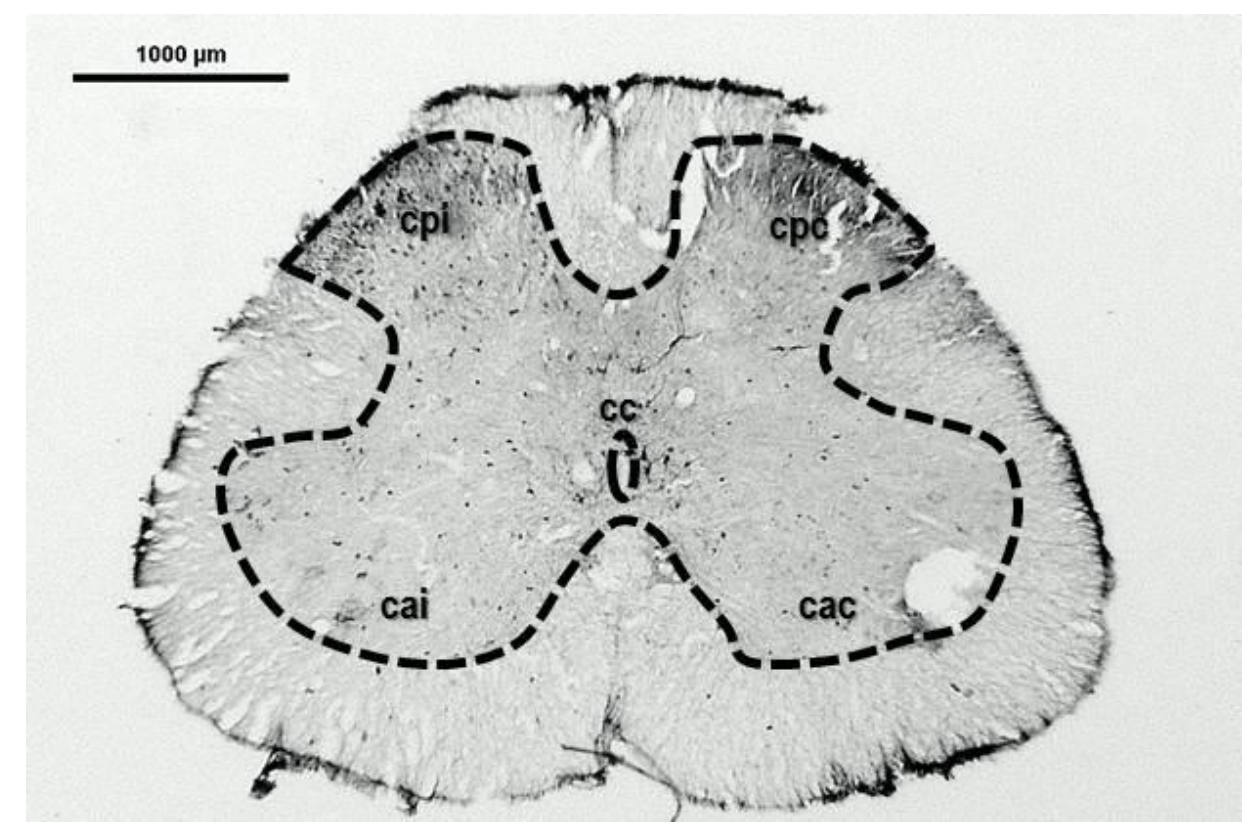

A área maior em destaque corresponde à substância cinzenta da medula espinal ao nível da intumescência lombo-sacral, onde se identifica a coluna posterior ipsilateral (cpi) e contralateral (cpl), a coluna anterior ipsilateral (cai) e contralateral (cal) e em destaque menos o canal central (cc).

FONTE: Laboratório de Neuroanatomia Funcional Dor. Departamento de Anatomia. Instituto de Ciências Biomédicas da Universidade de São Paulo (USP). 
Figura 15 - Fotomicrografias em campo claro de cortes semi-seriados imunorreativos para detecção de nNOS na medula espinal

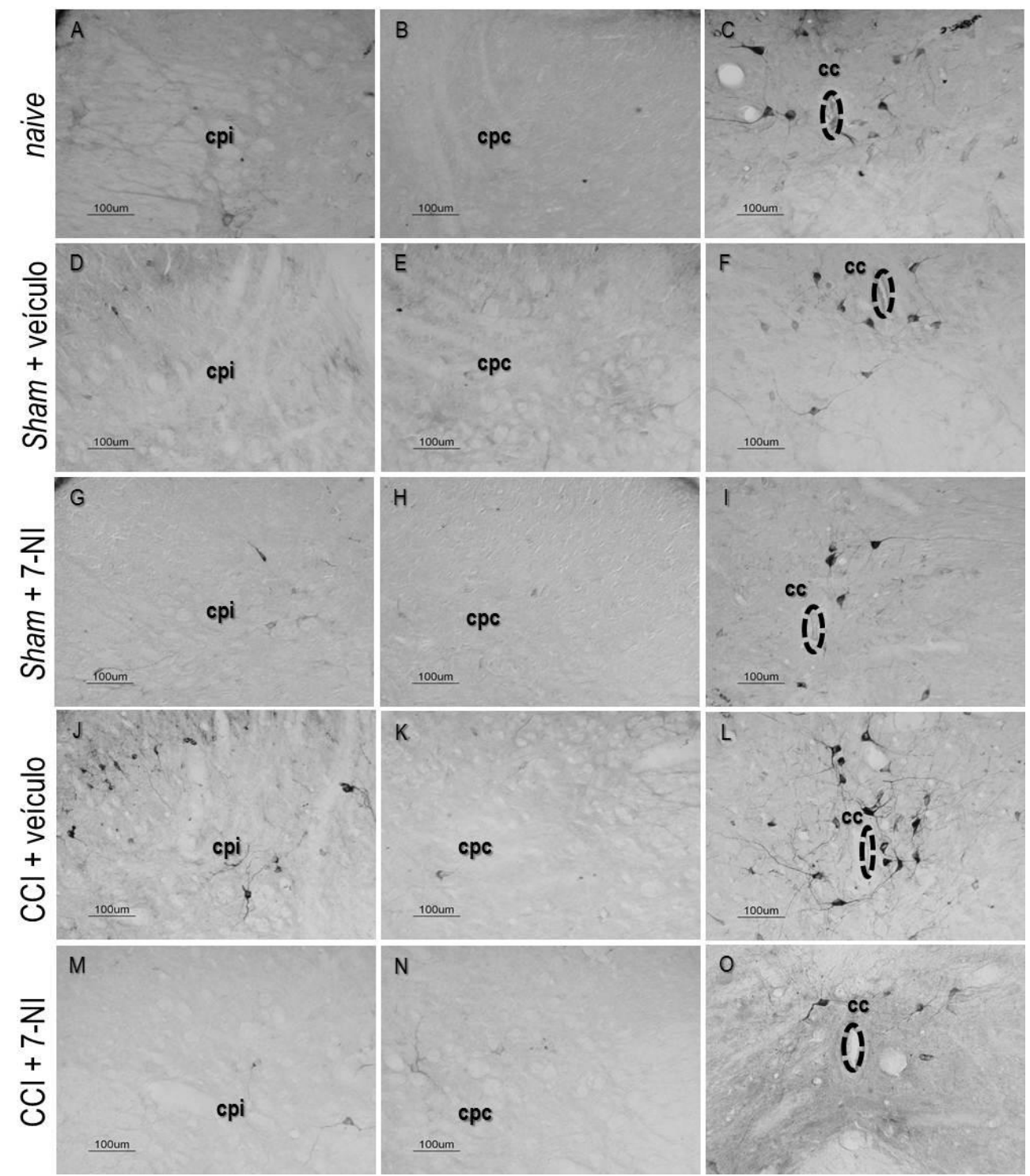

A primeira coluna corresponde as imagens de cortes da medula espinal ao nível da intumescência lombo-sacral evidenciando a coluna posterior ipsilateral a lesão (cpi) nos diferentes grupos experimentais. Observa-se o mesmo na segunda coluna, porém para o lado contralateral a lesão (cpc). A terceira coluna corresponde às imagens de cortes da medula espinal ao nível da intumescência lombo-sacral evidenciando a região do canal central (cc).

FONTE: Laboratório de Neuroanatomia Funcional Dor. Departamento de Anatomia. Instituto de Ciências Biomédicas da Universidade de São Paulo (USP).

\subsubsection{Efeito da CCI sobre a síntese de iNOS na medula espinal}

Em relação à enzima iNOS, como descrito na metodologia, realizamos análise por imunofluorescência uma vez que não conseguimos observar esta enzima utilizando a técnica com o cromógeno DAB. Foi analisada a porção lombo-sacral da medula espinal, mais especificamente as lâminas I-IV e lâmina X (ao redor do canal central). Foi observado 
aumento da síntese de iNOS principalmente ao redor do canal central, próximo à comissura branca, como observado na figura 16.

Nossos resultados demonstraram aumento da imunorreatividade para iNOS nos cortes da medula espinal dos grupos com lesão e a diminuição desta imunofluorescência nos animais tratados com o inibidor.

Figura 16 - Fotomicrografias em campo escuro de cortes semi-seriados imunorreagidos para detecção de iNOS da medula espinal
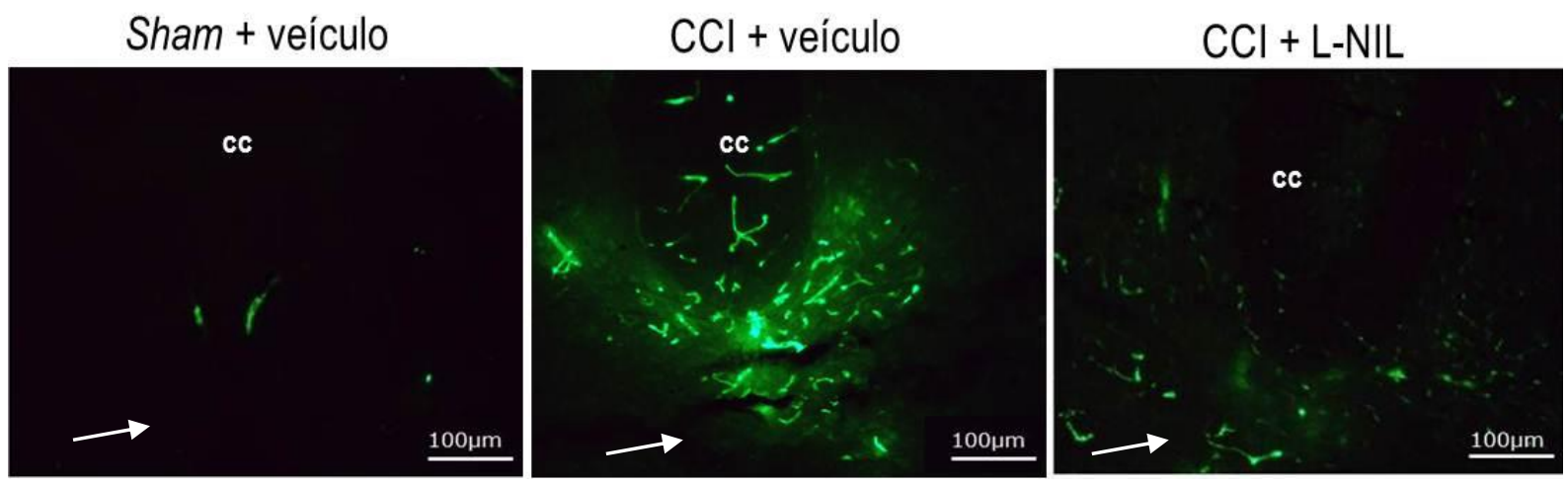

Comparação entre os diferentes grupos experimentais, observa-se imunorreação para iNOS próximo ao canal central (cc) principalmente na região da comissura branca, indicado pela seta branca.

FONTE: Laboratório de Neuroanatomia Funcional Dor. Departamento de Anatomia. Instituto de Ciências Biomédicas da Universidade de São Paulo (USP).

\subsubsection{Efeito da CCI sobre a síntese de nNOS no DRG}

Observamos maior reatividade para a enzima nNOS em células dos gânglios da raiz posterior da medula espinal (DRG's) nos animais dos grupos CCI quando comparados aos animais do grupo naive. Uma dupla marcação com traçador neuronal (Neuro Trace) indica os corpos celulares desses neurônios (Figura 17). 
Figura 17 - Fotomicrografias em campo escuro de cortes semi-seriados imunorreagidos para detecção de nNOS em DRG

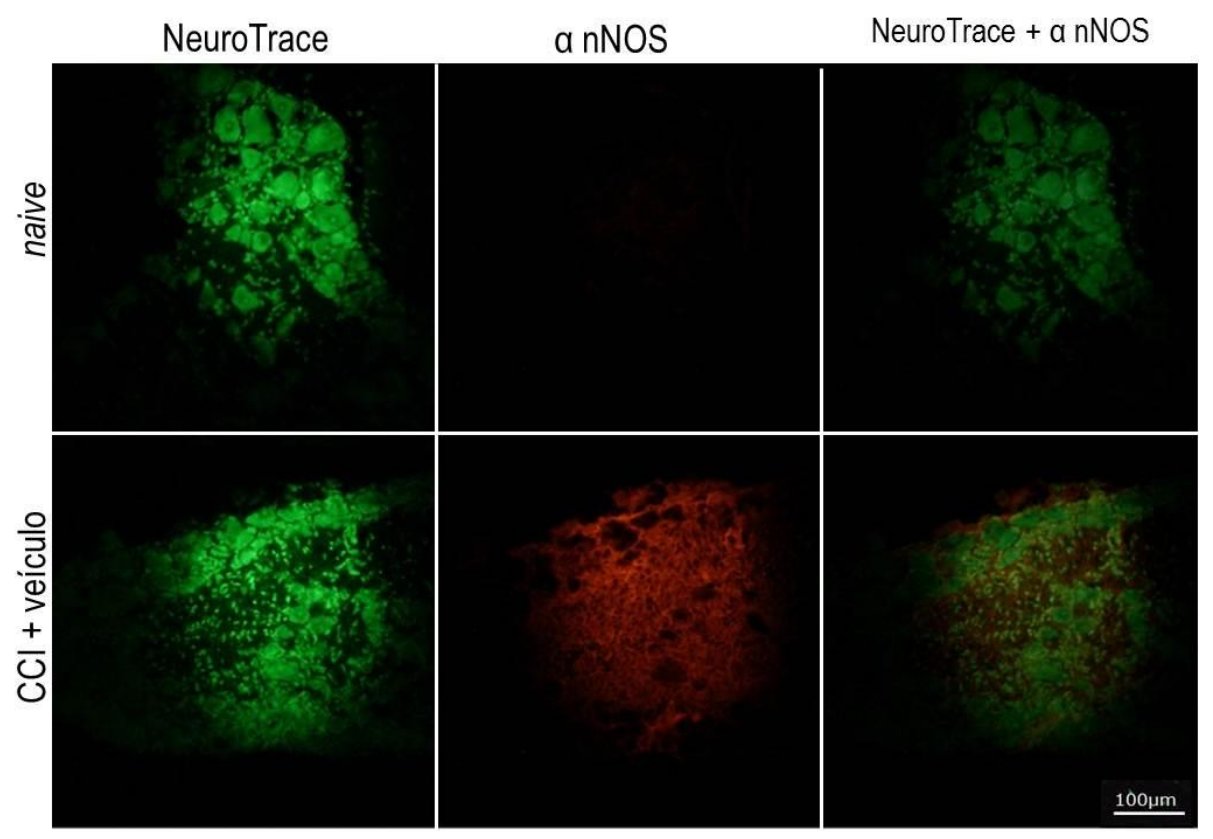

Comparação entre os grupos naive e CCI + veículo. A última coluna mostra a sobreposição das imagens de NeuroTrace e $\alpha$ nNOS.

FONTE: Laboratório de Neuroanatomia Funcional Dor. Departamento de Anatomia. Instituto de Ciências Biomédicas da Universidade de São Paulo (USP).

\subsubsection{Efeito da CCI sobre a síntese de iNOS no DRG}

Foi possível observar reatividade para iNOS nas chamadas células satélites, presentes no gânglio da raiz posterior da medula espinal (DRG), que ficam ao redor dos corpos neuronais, reagidos com traçador neuronal (Neuro Trace) (Figura 18).

Nossos resultados demonstraram menor imunorreatividade para iNOS experimentais tratados com o inibidor L-NIL (CCI + LNIL) quando comparados ao grupo CCI. 
Figura 18 - Fotomicrografias em campo escuro de cortes semi-seriados imunorreagidos para detecção de iNOS em DRG

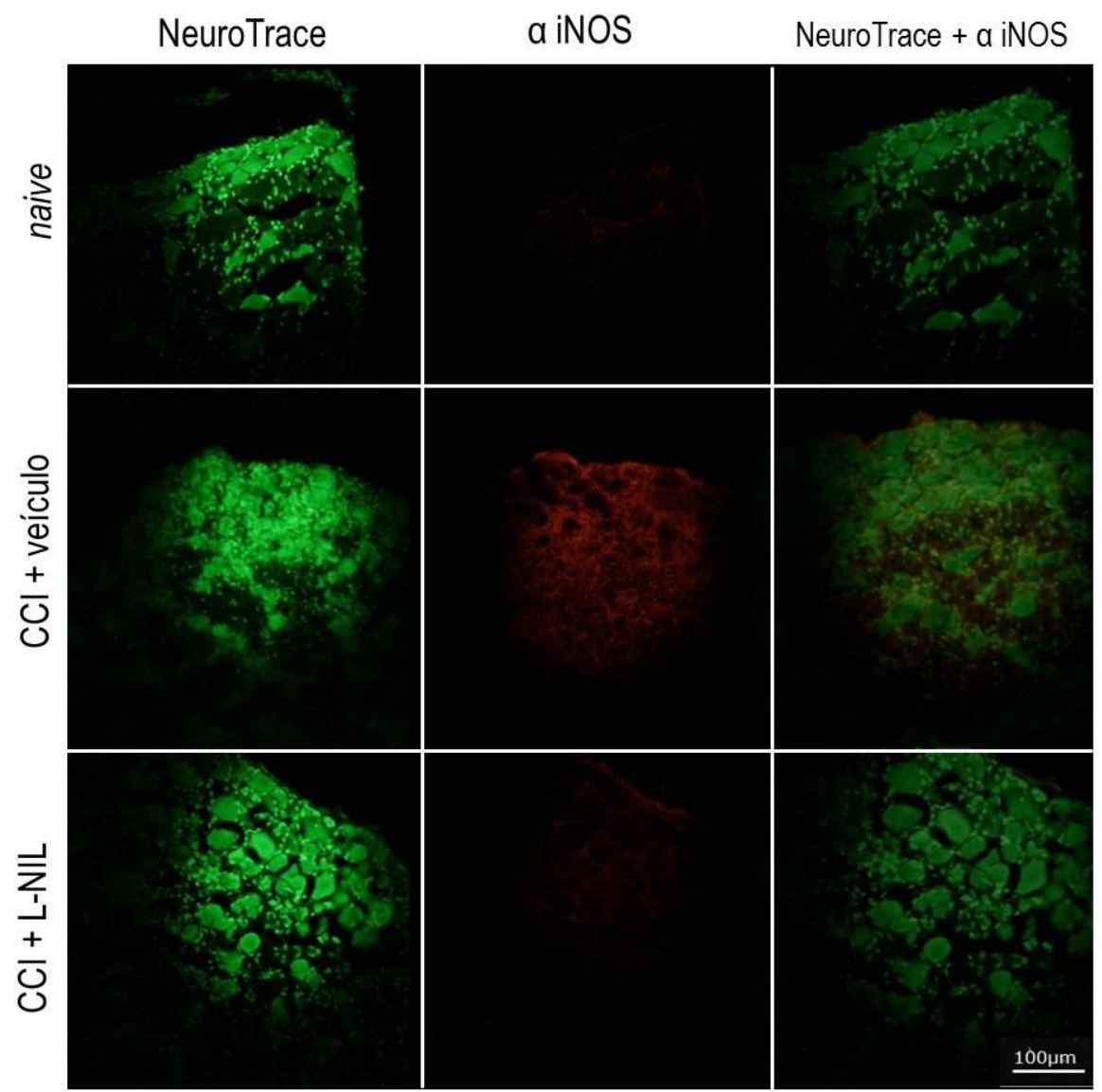

Comparação entre os diferentes grupos experimentais. A terceira coluna mostra a sobreposição das imagens de Neuro Trace e $\alpha$ iNOS

FONTE: Laboratório de Neuroanatomia Funcional Dor. Departamento de Anatomia. Instituto de Ciências Biomédicas da Universidade de São Paulo (USP).

\subsection{Western blot}

A análise dos dados com os experimentos de immunoblotting do lado ipsilateral da porção lombossacral (L6-L3) da medula espinal e dos gânglios da raiz posterior (L6-L3/ n=2) mostrou um perfil da modulação de síntese de nNOS e iNOS semelhante ao encontrado nos ensaios de imuno-histoquímica.

Apenas os dados de Western blot foram utilizados para avaliar quantitativamente os resultados dos diferentes grupos. Os ensaios de imuno-histoquímica foram considerado como semi-quantitativo. 


\subsubsection{Efeito da CCI sobre a síntese de nNOS na medula espinal}

Podemos observar aumento de $63 \%$ na densidade óptica das bandas marcadas para isoforma nNOS no $14^{\circ}$ dia pós-lesão (Figura 19) quando comparada as bandas dos grupos naive. As bandas do grupo CCI mais inibidor específico da isoforma (7-NI) apresentaram redução de $38 \%$ em comparação ao grupo CCI mais o veículo de diluição. Os resultados estão representados em gráficos para os diferentes grupos e ilustrados por imagens das bandas imunorreativas. A densidade média para o grupo controle naive foi sempre considerada $100 \%$. Não foi possível observar diferença significativa nas bandas incubadas com $\beta$-actina.

Figura 19 - Síntese de nNOS na medula espinal

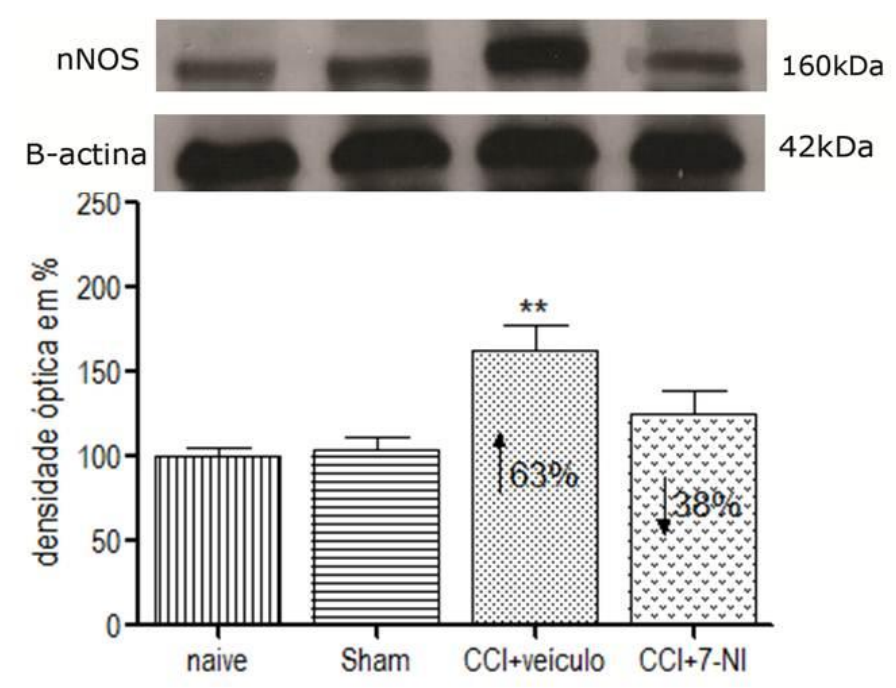

Analise da intumescência lombossacral de ratos. Os resultados representam em por cento a média \pm epm de cinco animais por grupo. **p $<0.005$, comparação entres os grupos. Para grupos CCI+veículo, Sham e naive $\mathrm{n}=5$ e para o grupo CCI+7-NI $\mathrm{n}=4$.

FONTE: Laboratório de Neuroanatomia Funcional Dor. Departamento de Anatomia. Instituto de Ciências Biomédicas da Universidade de São Paulo (USP).

\subsubsection{Efeito da CCI sobre a síntese de iNOS na medula espinal}

Podemos observar aumento de 69\% na densidade óptica das bandas marcadas para isoforma iNOS no $14^{\circ}$ dia pós-lesão (Figura 20), quando comparada as bandas do grupo naive (controle). As bandas do grupo CCI mais inibidor específico da isoforma (L-NIL) apresentaram redução de $51 \%$ em comparação ao grupo CCI mais o veículo de diluição, aproximando-se à média das bandas do grupo Sham. Os resultados estão representados em gráficos para os diferentes grupos e ilustrados por imagens das bandas imunorreativas. A 
densidade média para o grupo controle naive foi sempre considerada $100 \%$. A $\beta$-actina foi utilizada como controle da reação e não foi possível observar alterações entre os grupos analisados.

Figura 20 - Síntese de iNOS na medula espinal

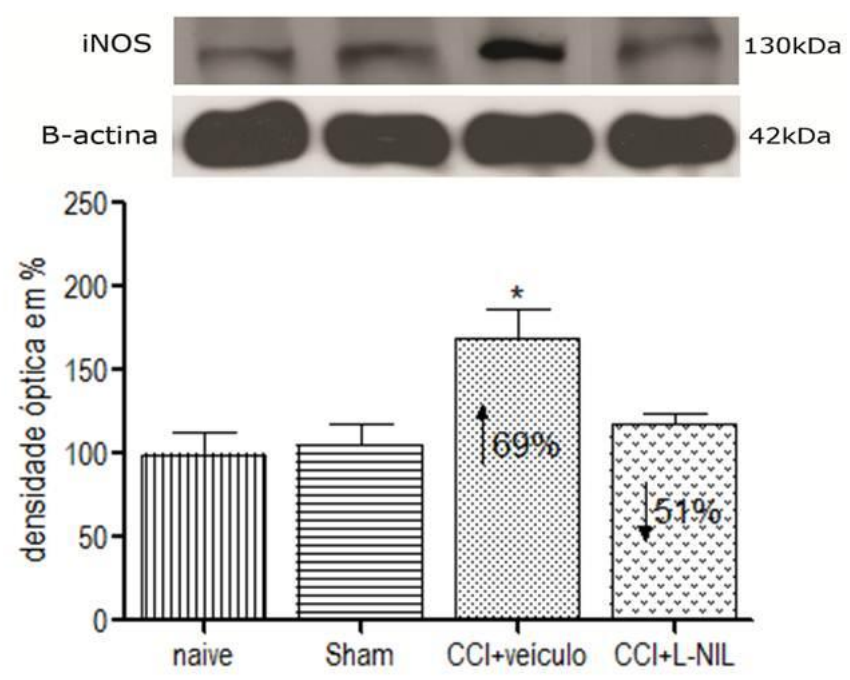

Análise da intumescência lombossacral de ratos. Os resultados representam em por cento a média \pm epm de cinco animais por grupo. *p <0.005, comparação entres os grupos.

FONTE: Laboratório de Neuroanatomia Funcional Dor. Departamento de Anatomia. Instituto de Ciências Biomédicas da Universidade de São Paulo (USP).

\subsubsection{Efeito da CCI sobre a síntese de nNOS nos DRG's}

Observamos aumento de 109\% na densidade óptica das bandas marcadas para isoforma nNOS no $14^{\circ}$ dia pós-lesão (Figura 21), quando comparada as bandas do grupo Sham (controle). As bandas do grupo CCI mais inibidor específico da isoforma (7-NI) apresentaram redução de $103 \%$ em comparação ao grupo CCI mais o veículo de diluição. Os resultados estão representados em gráficos para os diferentes grupos e ilustrados por imagens das bandas imunorreativas. A densidade média para o grupo controle (Sham) foi sempre considerada $100 \%$. Não foi possível observar diferença nas bandas incubadas com $\beta$-actina. 
Figura 21 - Síntese de nNOS em DRG's

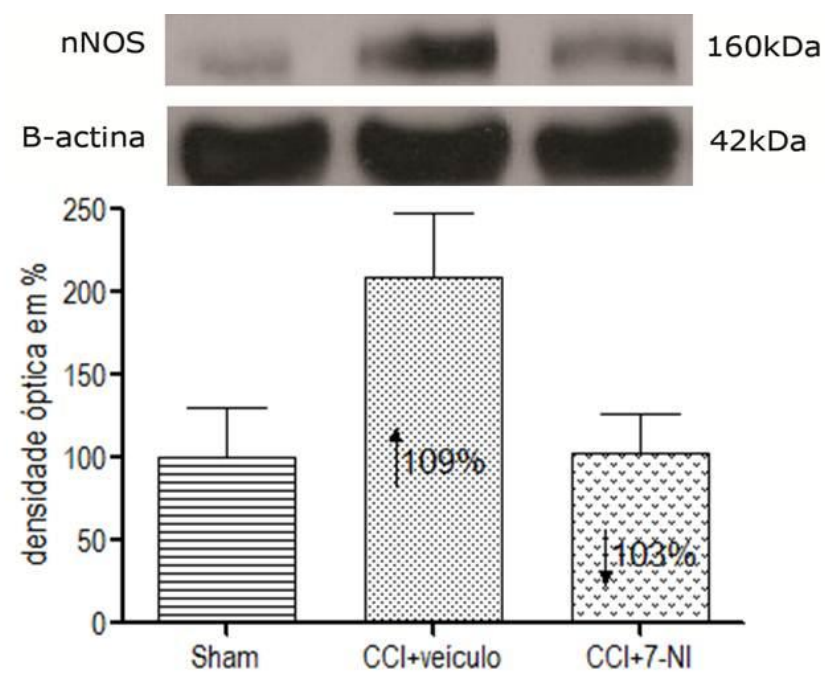

Analise do gânglio da raiz posterior (L3-L6). Os resultados representam em por cento a média \pm epm de cinco animais por grupo.

FONTE: Laboratório de Neuroanatomia Funcional Dor. Departamento de Anatomia. Instituto de Ciências Biomédicas da Universidade de São Paulo (USP).

\subsubsection{Efeito da CCI sobre a síntese de iNOS nos DRG's}

Podemos observar aumento de 38\% na densidade óptica das bandas marcadas para isoforma iNOS no $14^{\circ}$ dia pós-lesão (Figura 22), quando comparada as bandas do grupo Sham (controle). Apesar desta diminuição, não foi possível observar diferença significativa entre os grupos. As bandas do grupo CCI mais inibidor específico da isoforma (L-NIL) apresentaram redução de $41 \%$ em comparação ao grupo CCI, aproximando-se à média das bandas do grupo Sham. Os resultados estão representados em gráficos para os diferentes grupos e ilustrados por imagens das bandas imunorreativas. A densidade média para o grupo controle (Sham) foi sempre considerada $100 \%$. A $\beta$-actina foi utilizada como controle da reação e não foi possível observar alterações entre os grupos analisados. 
Figura 22 - Síntese de iNOS em DRG’s

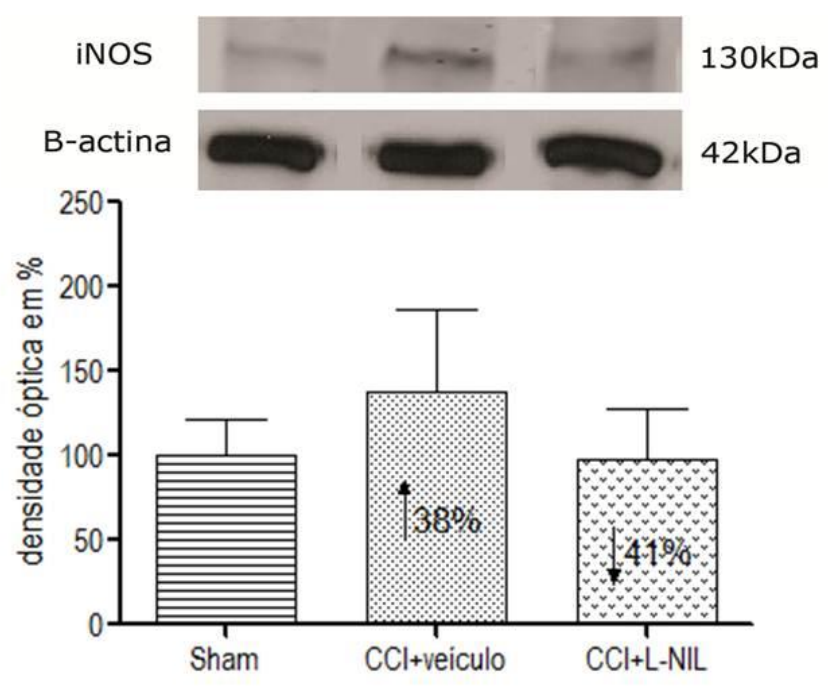

Análise dos gânglios da raiz posterior (L3-L6). Os resultados representam em por cento a média \pm epm de cinco animais por grupo.

FONTE: Laboratório de Neuroanatomia Funcional Dor. Departamento de Anatomia. Instituto de Ciências Biomédicas da Universidade de São Paulo (USP).

\subsection{Detecção do NO através do uso de DAF-2 DA}

Por meio do estudo da detecção do NO observamos a produção de NO na porção lombossacral da medula espinal e nos DRG's de ratos do grupo naive e CCI, após uma hora de incubação para os ensaios com tecidos congelados e reativados, cortes de $20 \mu \mathrm{m}$. Foi possível notar nos cortes do grupo CCI aumento da intensidade da fluorescência em comparação ao grupo naive (Figura 23 e 25), indicando aumento da produção de NO, nos locais analisados (coluna posterior, canal central e DRG).

O mesmo padrão de reatividade foi observado na porção lombossacral da medula espinal dos ensaios com tecido in vivo que foram incubados por 30' com a probe DAF-2 DA,

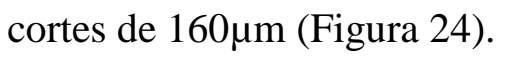


Figura 23 - Reatividade da probe DAF-2 DA em corte transversal da medula

naive

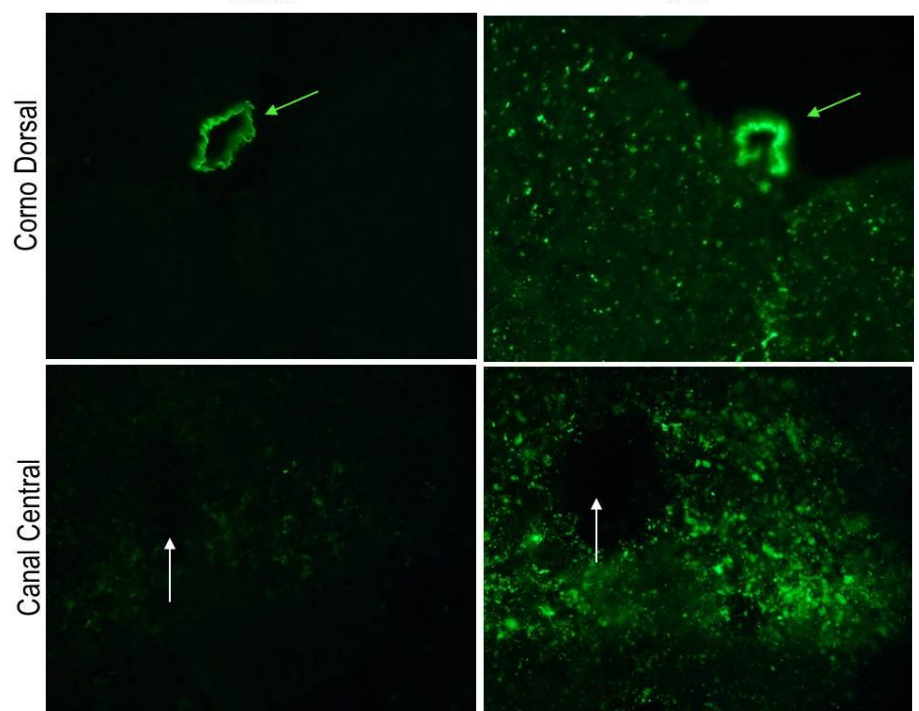

Observa-se marcação fluorescente mais intensa na coluna posterior e ao redor do canal central da medula espinal dos animais CCI em comparação ao naive. Senta verde indica a artéria espinal posterior, aumento 20x.

FONTE: Laboratório de Neuroanatomia Funcional Dor. Departamento de Anatomia. Instituto de Ciências Biomédicas da Universidade de São Paulo (USP).

Figura 24 - Reatividade da probe DAF-2 DA em corte transversal da medula espinal - in vivo naive $\mathrm{CCl}$

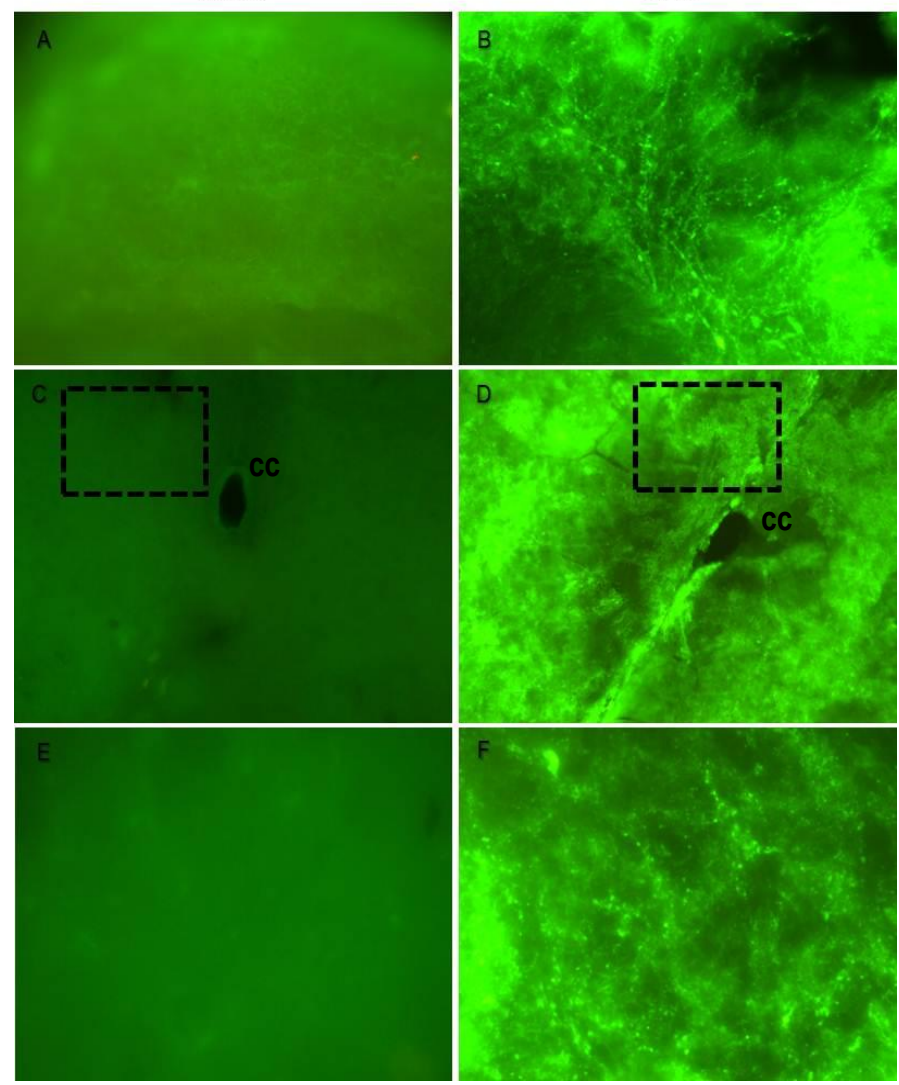

Em A e B coluna posterior, aumento 20x. Em C e D, canal central (cc), aumento 10x. Em E e F região adjacente ao cc, área em destaque em $\mathrm{C}$ e D, aumento 20x

FONTE: Laboratório de Neuroanatomia Funcional Dor. Departamento de Anatomia. Instituto de Ciências Biomédicas da Universidade de São Paulo (USP). 
Figura 25 - Reatividade da probe DAF-2 DA em cortes de DRG's

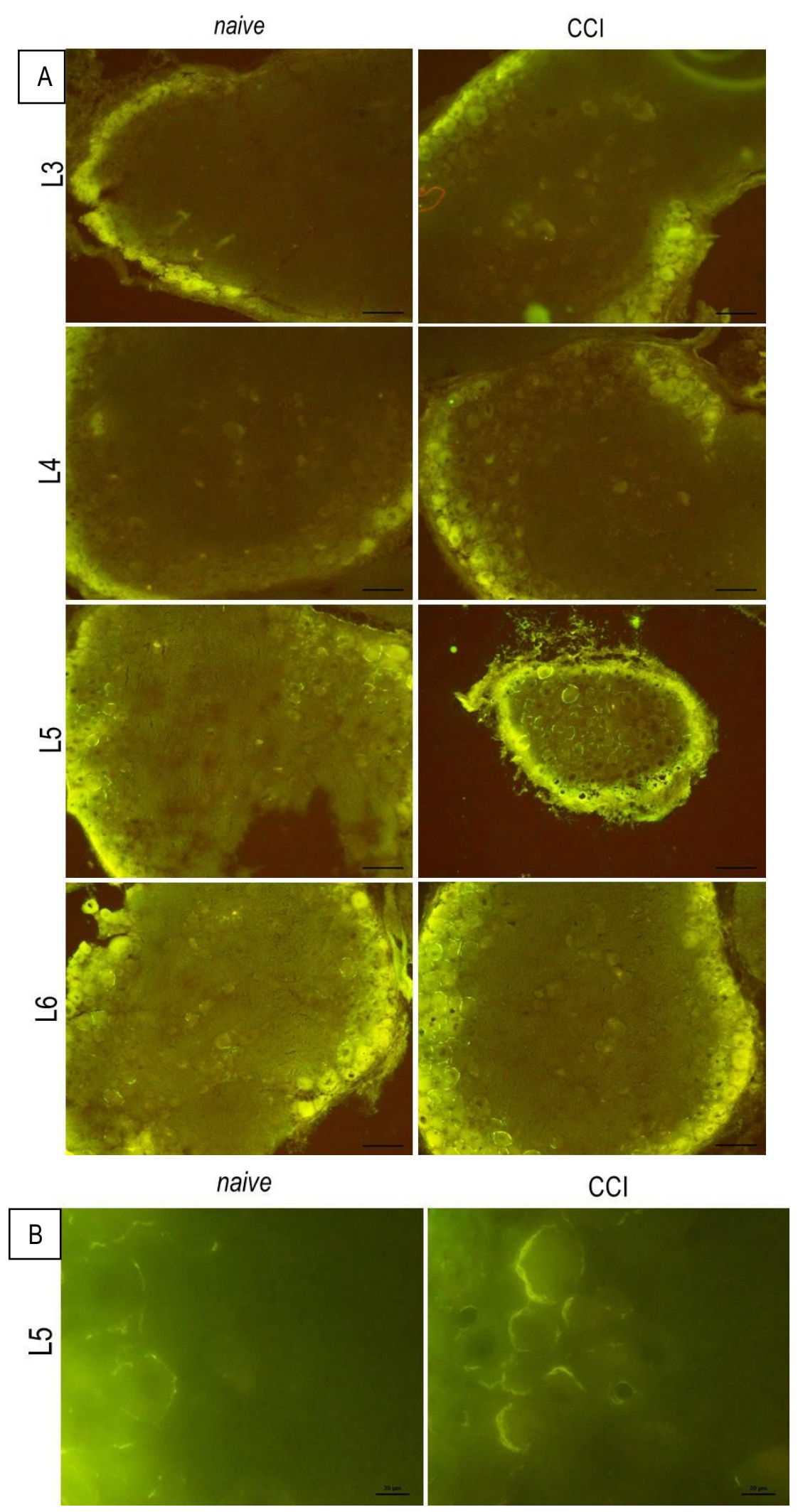

Em A comparação da reatividade entre os grupos naive e CCI nos DRG's de L3 a L6, aumento 20x. E B detalhe da reatividade observada em L5, aumento 40x.

FONTE: Laboratório de Neuroanatomia Funcional Dor. Departamento de Anatomia. Instituto de Ciências Biomédicas da Universidade de São Paulo (USP). 


\section{DISCUSSÃO}

Durante a sensibilização central, em modelos animais de dor neuropática e inflamatória, foi observado que o aumento na síntese das isoformas neuronal e induzível da NOS está relacionada com centros de modulação nociceptiva espinal e ganglionar (CallsenCencic et al., 1999; Gordh et al., 1998). Entretanto, também existem relatos de nenhuma alteração ou redução destas expressões, em relação a diferentes técnicas de detecção, espécies animais e modelos de lesão (Callsen-Cencic et al., 1999; Goff et al., 1998).

Em nossas analises a CCI se mostrou eficiente no $14^{\circ}$ dia pós-lesão permitindo a padronização do modelo. Esta observação é baseada em nossos resultados obtidos nos testes comportamentais, onde se avaliou a resposta hiperalgésica e alodínica dos animais após a lesão. Constatamos diminuição do limiar nociceptivo dos animais no $14^{\circ}$ dia pós-lesão, quando comparadas às medidas iniciais (MI), demonstrando assim o bom funcionamento do modelo experimental, corroborando aos dados apresentados por Bennett e Xie (1988) que descreveram inicialmente este modelo e aos trabalhos que demonstram que a injúria do nervo periférico resulta em dor neuropática persistente ou crônica, caracterizada por dor espontânea em queimação, acompanhada de alodinia e hiperalgesia (Chacur et al., 2010; Payne e Norfleet, 1986; Tanabe et al., 2009).

A manipulação farmacológica de NO através de várias vias de administração têm confirmado o comprometimento funcional do NO em estados de dor, no local da lesão, na periferia e no SNC, todos contribuindo para a sensibilização central (Little et al., 2010). Por existirem trabalhos que mostram o envolvimento da NOS tanto em modelos de lesão crônica como inflamatória, e outros que mostram o inverso, pretendemos com este projeto, tentar compreender melhor o papel da NOS no modelo de lesão crônica. Para confirmação destes dados, avaliamos o efeito da administração intratecal de inibidor seletivo (7-NI) da isoforma neuronal (nNOS) na resposta nociceptiva induzida pela lesão. Nossos resultados demonstram que este inibidor foi capaz de reverter significativamente à resposta hiperalgésica no $14^{\circ}$ dia pós-lesão quando comparado ao grupo CCI que não recebeu o tratamento com inibidor. Observamos essa resposta tanto nos testes para hiperalgesia mecânica ou térmica, quanto para a alodinia. Ambos os resultados corroboram aos dados descritos na literatura, onde foi observado o mesmo padrão de resposta (Guan et al., 2007; Tanabe et al., 2009).

Quanto a participação da isoforma indizível (iNOS), o inibidor seletivo, L-NIL foi capaz de reverter parcialmente a resposta hiperalgésica mecânica e térmica, no entanto, não foi capaz de interferir com a resposta alodínica induzida no presente modelo experimental, 
Chacur et al. (2004) e Tanabe et al. (2009) observaram resultados similares, quando utilizaram o mesmo inibidor, L-NIL. No entanto, estudos recentes têm sugerido tanto a contribuição espinal quanto periférica da iNOS na hipersensibilidade mecânica após a ligadura do nervo espinal (LaBuda et al., 2006) ou apenas a sua contribuição para a hipersensibilidade mecânica periférica após lesão constritiva crônica do nervo isquiático (De Alba et al., 2006).

Igualmente, o papel específico das isoformas da NOS na dor também tem sido investigado por manipulação genética, com resultados conflitantes. Animais com deleção de nNOS demonstraram atenuação na hiperalgesia inflamatória tardia, mas não na inicial (Chu et al., 2005; Tao et al., 2004). A supressão de iNOS parece ter nenhum efeito sobre a hiperalgesia induzida pela carragenina (Tao et al., 2003), porém, a falta de iNOS reduziu a hiperalgesia térmica inicial induzida por zymosan (Guhring et al., 2000). Além disso, Boettger et al. (2007) relataram que animais knockout para nNOS apresentaram reduções significativas da hiperalgesia térmica e ausência de hiperalgesia mecânica em resposta ao adjuvante completo de Freund (CFA). Outro estudo utilizando CFA demonstrou que camundongos knockout para iNOS tiveram redução na hiperalgesia térmica e no edema, enquanto camundongos knockout para nNOS reduziram o edema e a alodinia mecânica, bem como uma modesta recuperação rápida da hiperalgesia térmica em comparação aos camundongos selvagens (Leanez et al., 2009); (Little et al., 2010).

Em quais células o NO é produzido no decorrer do processamento nociceptivo é uma questão de debate há algum tempo. Durante o processamento da dor persistente, nota-se considerável aumento na síntese de nNOS, porém os neurônios recrutados para essa síntese diferem dependendo do tipo de dor (Schmidtko et al., 2009). Durante a dor inflamatória evocadas por injeção na pata de agentes pró-inflamatórios como formalina, zymosan ou adjuvante completo de Freund, nNOS é regulada positivamente em interneurônios inibitórios do coluna posterior (Chu et al., 2005; Yonehara et al., 1997).

Nossos resultados de imuno-histoquímica sugerem o envolvimento da nNOS no presente modelo experimental. Ao analisarmos os cortes de medula dos animais com CCI, observamos pequeno número de células imunorreativas para nNOS no lado contralateral, enquanto, no lado ipsilateral, observamos aumento expressivo da imunorreatividade ao redor do canal central (lâmina X) e na coluna posterior da medula espinal (lâminas I-III). No DRG (L5) também notamos aumento dessa imunorreatividade nos animais do grupo CCI em comparação aos animais do grupo naive. 
Após o tratamento com inibidor específico desta isoforma (7-NI), foi possível observar a reversão deste quadro, ou seja, observamos a diminuição das células imunorreativas no lado ipsilateral dos animais com CCI que receberam tratamento com inibidor, quando comparado com animais controle (que receberam o veículo de diluição).

Esses resultados vão ao encontro das análises de imuno-histoquímica que relataram células nNOS positivas (Chacur et al., 2010) e NADPH-d positivas (Anderson, 1992) em neurônios com soma no interior das lâminas I a III e também na lâmina X, tanto constitutivamente, participando de respostas autonômicas, quanto em decorrência à lesão no nervo periférico. Ainda, alguns estudos demonstram síntese constitutiva da nNOS em subconjunto de neurônios com o soma no interior da lâmina II, plexos de fibras nas lâminas IIII da coluna posterior da medula espinal e em apenas alguns neurônios dos DRG's da porção lombar (<5\%) (Aimi et al., 1991; Ruscheweyh et al., 2006; Valtschanoff et al., 1992).

Em contrapartida, alguns autores demonstram que durante a dor neuropática em resposta à lesão do nervo periférico, nNOS é pouco regulada em neurônios da medula espinal, apresentando pequeno aumento na síntese de somas de neurônios no interior da lâmina X, porém, o número de neurônios nNOS positivos dos DRG's e a presença de nNOS em seus terminais centrais, os quais entram no coluna posterior, aumenta consideravelmente segundo Zhang et al. (1993) apud Schmidtko et al. (2009). Este aumento da produção de NO parece ser importante para a sobrevivência de neurônios dos DRG's após a lesão do nervo periférico, pois camundongos knockout para essa isoforma apresentam aumento da apoptose nesses neurônios (Luo et al., 1999; Maihofner et al., 2000; Zhang et al., 1993).

Dados sobre a distribuição e regulação de outras isoformas da NOS na medula espinal e nos DRG's são pouco consistentes. Em animais naive, a isoforma iNOS, quando muito, é apenas fracamente sintetizada na medula espinal (Maihofner et al., 2000). Além disso, se a estimulação nociceptiva periférica leva ou não à indução da síntese de iNOS na medula espinal e nos DRG's permanece controverso. Alguns estudos demonstram que a isoforma iNOS é super regulada no tecido inflamado, outros demonstram aumento de mRNA da iNOS e/ou da proteína na medula espinal, em modelos de dor inflamatória e dor neuropática (De Alba et al., 2006; Guhring et al., 2000; Keilhoff et al., 2002).

Ao examinar a síntese de iNOS por imunofluorescência, em nosso modelo experimental, observamos aumento na imunorreatividade do iNOS provavelmente em células gliais (devido a marcação observada em células satélites ao redor dos corpos neuronais) em comparação aos animais controles e diminuição após o tratamento com o respectivo inibidor em ambos os tecidos. 
As análises de Western blot validam os resultados imuno-histoquímicos, pois o mesmo padrão de resposta pode ser observado. As amostras de medula dos animais com CCI apresentaram $63 \%$ de aumento na síntese de nNOS em comparação aos animais naive e uma diminuição de $38 \%$ nos animais tratados com o inibidor 7-NI em comparação aos animais com CCI. As amostras dos DRG's, da mesma maneira, apresentaram aumento de 109\% e diminuição de $103 \%$ após tratamento com inibidor.

Em relação à síntese de iNOS, observamos na medula espinal aumento de $69 \%$ nos animais com CCI e diminuição de $51 \%$ na imunorreatividade dos animais que receberam o inibidor L-NIL, igualmente, nos DRG's os animais apresentaram aumento de $38 \%$ e diminuição de $41 \%$ após tratamento. Ainda, foi observado síntese basal de iNOS menor que na detecção de nNOS, novamente corroborando aos dados de imuno-histoquímica e também ao observado por Maihofner (2000) que sugere pouca ou nenhuma síntese de iNOS em animais naive. Mais uma vez, esses dados de Western blot, reforçam além dos nossos resultados imuno-histoquímicos os resultados observados nos testes comportamentais, permitindo sugerir o envolvimento de ambas às isoformas na modulação central durante o processamento nociceptivo em resposta ao modelo experimental de lesão constritiva crônica do nervo isquiático.

Para observar a distribuição de óxido nítrico na porção lombossacral da medula, realizamos ensaios utilizando marcador fluorescente DAF2-DA. Duas técnicas foram realizadas, na primeira, segundo Mabuchi (2003), a reatividade da probe mostrou-se maior nos animais com CCI em comparação aos animais naive, as respostas foram similares nos animais dos mesmos grupos na segunda técnica, descrito a seguir.

Na segunda técnica, segundo Torrão e Britto (2004), observamos aumento na produção de NO principalmente na coluna posterior, ao redor do canal central e nos somas no interior dos DRG's, além disso, pudemos notar dispersão da reatividade nas áreas adjacentes. Vale ressaltar que os cortes na primeira técnica são de $160 \mu \mathrm{m}$ enquanto na segunda são de $20 \mu \mathrm{m}$ o que permite melhor localização das áreas de produção do NO, porém, a primeira técnica por manter o tecido in vivo demonstra de modo mais fidedigno a produção do NO, por isso a realização de ambas as técnicas.

Baseado em nossos resultados e nos dados descritos na literatura podemos então sugerir a participação do NO, liberado pela nNOS, atuando como modulador na transmissão nociceptiva, pois a inibição da enzima nNOS foi capaz de reverter ou reduzir a sensibilização induzida pela constrição do nervo isquiático, tanto na resposta hiperalgésica quanto na alodínica, porém, a inibição da isoforma induzível reduziu a resposta hiperalgésica mas não 
alodínica o que possivelmente demonstra parcial e pontual participação da iNOS. Nossos resultados e os dados descritos na literatura ainda são controversos para esta isoforma, mais estudos devem ser realizados para a melhor compreensão.

Sendo assim nota-se a possível contribuição de ambas as isoformas em mecanismos de sensibilização central. 


\section{REFERÊNCIAS*}

(IASP) IAFTSOP. Pain terms: a current list definitions and notes on usage. . Pain, 1986;3:S1521.

Aimi Y, Fujimura M, Vincent SR, Kimura H. Localization of NADPH-diaphorase-containing neurons in sensory ganglia of the rat. J Comp Neurol, 1991;306(3):382-92.

Alderton WK, Cooper CE, Knowles RG. Nitric oxide synthases: structure, function and inhibition. Biochem J, 2001;357(Pt 3):593-615.

Allan SM, Rothwell NJ. Inflammation in central nervous system injury. Philos Trans R Soc Lond B Biol Sci, 2003;358(1438):1669-77.

Alvarez FJ, Fyffe RE. Nociceptors for the 21st century. Curr Rev Pain, 2000;4(6):451-8.

Anderson CR. NADPH diaphorase-positive neurons in the rat spinal cord include a subpopulation of autonomic preganglionic neurons. Neurosci Lett, 1992;139(2):280-4.

Babbedge RC, Bland-Ward PA, Hart SL, Moore PK. Inhibition of rat cerebellar nitric oxide synthase by 7-nitro indazole and related substituted indazoles. $\mathrm{Br} \mathrm{J}$ Pharmacol, 1993;110(1):225-8.

Basbaum AI, Bautista DM, Scherrer G, Julius D. Cellular and molecular mechanisms of pain. Cell, 2009;139(2):267-84.

Basbaum AI, Gautron M, Jazat F, Mayes M, Guilbaud G. The spectrum of fiber loss in a model of neuropathic pain in the rat: an electron microscopic study. Pain, 1991;47(3):359-67.

Basbaum AIJ, T. . The perception of pain. In: Kandel ERS, J.; Jessell, T., editor. book title. New York: :Appleton and Lange, 2000;p472-91.

Beckman JS, Koppenol WH. Nitric oxide, superoxide, and peroxynitrite: the good, the bad, and ugly. Am J Physiol, 1996;271(5 Pt 1):C1424-37.

Bennett GJ, Xie YK. A peripheral mononeuropathy in rat that produces disorders of pain sensation like those seen in man. Pain, 1988;33(1):87-107.

Biro D. Is there such a thing as psychological pain? And why it matters. Cult Med Psychiatry, 2010;34(4):658-67.

Bohme GA, Bon C, Lemaire M, et al. Altered synaptic plasticity and memory formation in nitric oxide synthase inhibitor-treated rats. Proc Natl Acad Sci U S A, 1993;90(19):9191-4.

Bradford MM. A rapid and sensitive method for the quantitation of microgram quantities of protein utilizing the principle of protein-dye binding. Anal Biochem, 1976;72:248-54.

* De acordo com:

International Committee of Medical Journal Editors. Uniform requirements for manuscripts submitted to biomedical journals. Available from: http://www.nlm.nih.gov/bsd/uniform_requirements.html [2007 May 22]. 
Bredt DS, Ferris CD, Snyder SH. Nitric oxide synthase regulatory sites. Phosphorylation by cyclic AMP-dependent protein kinase, protein kinase $\mathrm{C}$, and calcium/calmodulin protein kinase; identification of flavin and calmodulin binding sites. J Biol Chem, 1992;267(16):10976-81.

Bromm B, Treede RD. Human cerebral potentials evoked by $\mathrm{CO} 2$ laser stimuli causing pain. Exp Brain Res, 1987;67(1):153-62.

Burgess PR, Perl ER. Myelinated afferent fibres responding specifically to noxious stimulation of the skin. J Physiol, 1967;190(3):541-62.

Callsen-Cencic P, Hoheisel U, Kaske A, Mense S, Tenschert S. The controversy about spinal neuronal nitric oxide synthase: under which conditions is it up- or downregulated? Cell Tissue Res, 1999;295(2):183-94.

Campbell JN, Meyer RA. Mechanisms of neuropathic pain. Neuron, 2006;52(1):77-92.

Chacur M, Matos RJ, Alves AS, et al. Participation of neuronal nitric oxide synthase in experimental neuropathic pain induced by sciatic nerve transection. Braz J Med Biol Res, 2010;43(4):367-76.

Chaplan SR, Bach FW, Pogrel JW, Chung JM, Yaksh TL. Quantitative assessment of tactile allodynia in the rat paw. Journal of Neuroscience Methods, 1994;53:55-63.

Chu YC, Guan Y, Skinner J, et al. Effect of genetic knockout or pharmacologic inhibition of neuronal nitric oxide synthase on complete Freund's adjuvant-induced persistent pain. Pain, 2005;119(1-3):113-23.

Coggeshall RE, Hong KA, Langford LA, Schaible HG, Schmidt RF. Discharge characteristics of fine medial articular afferents at rest and during passive movements of inflamed knee joints. Brain Res, 1983;272(1):185-8.

Contestabile A. Roles of NMDA receptor activity and nitric oxide production in brain development. Brain Res Brain Res Rev, 2000;32(2-3):476-509.

Coutaux A, Adam F, Willer JC, Le Bars D. Hyperalgesia and allodynia: peripheral mechanisms. Joint Bone Spine, 2005;72(5):359-71.

Craig JA, Barron J, Walsh DM, Baxter GD. Lack of effect of combined low intensity laser therapy/phototherapy (CLILT) on delayed onset muscle soreness in humans. Lasers Surg Med, 1999;24(3):223-30.

De Alba J, Clayton NM, Collins SD, et al. GW274150, a novel and highly selective inhibitor of the inducible isoform of nitric oxide synthase (iNOS), shows analgesic effects in rat models of inflammatory and neuropathic pain. Pain, 2006;120(1-2):170-81.

Dong X, Han S, Zylka MJ, Simon MI, Anderson DJ. A diverse family of GPCRs expressed in specific subsets of nociceptive sensory neurons. Cell, 2001;106(5):619-32. 
Dusse LMS, Vieira LM, Carvalho MG. Revisão sobre óxido nítrico. Jornal Brasileiro de Patologia e Medicina Laboratorial, 2003;39(4):343- 50.

Ferreira SH, Duarte ID, Lorenzetti BB. The molecular mechanism of action of peripheral morphine analgesia: stimulation of the cGMP system via nitric oxide release. Eur J Pharmacol, 1991;201(1):121-2.

Finkel T, Holbrook NJ. Oxidants, oxidative stress and the biology of ageing. Nature, 2000;408(6809):239-47.

Fridovich I. Oxygen toxicity: a radical explanation. J Exp Biol, 1998;201(Pt 8):1203-9.

Furchgott RF, Zawadzki JV. The obligatory role of endothelial cells in the relaxation of arterial smooth muscle by acetylcholine. Nature, 1980;288(5789):373-6.

Gabbita SP, Robinson KA, Stewart CA, Floyd RA, Hensley K. Redox regulatory mechanisms of cellular signal transduction. Arch Biochem Biophys, 2000;376(1):1-13.

Garthwaite J. Glutamate, nitric oxide and cell-cell signalling in the nervous system. Trends Neurosci, 1991;14(2):60-7.

Gebhart GF. Descending modulation of spinal nociceptive processing. Schmerz, 1993;7(4):216-25.

George A, Buehl A, Sommer C. Tumor necrosis factor receptor 1 and 2 proteins are differentially regulated during Wallerian degeneration of mouse sciatic nerve. Exp Neurol, 2005;192(1):163-6.

Goff JR, Burkey AR, Goff DJ, Jasmin L. Reorganization of the spinal dorsal horn in models of chronic pain: correlation with behaviour. Neuroscience, 1998;82(2):559-74.

Gordh T, Sharma HS, Alm P, Westman J. Spinal nerve lesion induces upregulation of neuronal nitric oxide synthase in the spinal cord. An immunohistochemical investigation in the rat. Amino Acids, 1998;14(1-3):105-12.

Guan Y, Yaster M, Raja SN, Tao YX. Genetic knockout and pharmacologic inhibition of neuronal nitric oxide synthase attenuate nerve injury-induced mechanical hypersensitivity in mice. Mol Pain, 2007;3(1):29.

Guedes RP. Efeito da secção do nervo ciático, como modelo de dor neuropática, sobre marcadores de estresse oxidativo e defesas antioxidantes na medula espinal de ratos [thesis (Type in 2007)]. Porto Alegre: Universidade Federal do Rio Grande do Sul; 2007.

Guhring H, Gorig M, Ates M, et al. Suppressed injury-induced rise in spinal prostaglandin E2 production and reduced early thermal hyperalgesia in iNOS-deficient mice. J Neurosci, 2000;20(17):6714-20.

Guo K, Liu Y, Zhou H, et al. Involvement of protein kinase $\mathrm{C}$ beta-extracellular signalregulating kinase 1/2/p38 mitogen-activated protein kinase-heat shock protein 27 activation in hepatocellular carcinoma cell motility and invasion. Cancer Sci, 2008;99(3):486-96. 
Hargreaves K, Dubner R, Brown F, Flores C, Joris J. A new and sensitive method for measuring thermal nociception in cutaneous hyperalgesia. Pain, 1988;32:77-88.

Ignarro LJ, Byrns RE, Buga GM, Wood KS. Endothelium-derived relaxing factor from pulmonary artery and vein possesses pharmacologic and chemical properties identical to those of nitric oxide radical. Circ Res, 1987;61(6):866-79.

Jessell TM, Kelley KW. Pain and Analgesia. In: Kandell ERS, J.H.; Jessel, T.M, editor. book title., 1991;p385-99.

Julius D, Basbaum AI. Molecular mechanisms of nociception. Nature, 2001;413(6852):203-10.

Keilhoff G, Fansa H, Wolf G. Neuronal nitric oxide synthase is the dominant nitric oxide supplier for the survival of dorsal root ganglia after peripheral nerve axotomy. J Chem Neuroanat, 2002;24(3):181-7.

Kleinschnitz C, Brinkhoff J, Sommer C, Stoll G. Contralateral cytokine gene induction after peripheral nerve lesions: dependence on the mode of injury and NMDA receptor signaling. Brain Res Mol Brain Res, 2005;136(1-2):23-8.

Koeberle PD, Ball AK. Nitric oxide synthase inhibition delays axonal degeneration and promotes the survival of axotomized retinal ganglion cells. Exp Neurol, 1999;158(2):366-81.

LaBuda CJ, Koblish M, Tuthill P, Dolle RE, Little PJ. Antinociceptive activity of the selective iNOS inhibitor AR-C102222 in rodent models of inflammatory, neuropathic and post-operative pain. Eur J Pain, 2006;10(6):505-12.

Leanez S, Hervera A, Pol O. Peripheral antinociceptive effects of mu- and delta-opioid receptor agonists in NOS2 and NOS1 knockout mice during chronic inflammatory pain. Eur J Pharmacol, 2009;602(1):41-9.

Lee EJ, Kim KY, Gu TH, et al. Neuronal nitric oxide synthase is expressed in the axotomized ganglion cells of the rat retina. Brain Res, 2003;986(1-2):174-80.

Levy D, Kubes P, Zochodne DW. Delayed peripheral nerve degeneration, regeneration, and pain in mice lacking inducible nitric oxide synthase. J Neuropathol Exp Neurol, 2001;60(5):411-21.

Little JW, Doyle T, Salvemini D. Reactive nitroxidative species and nociceptive processing: determining the roles for nitric oxide, superoxide, and peroxynitrite in pain. Amino Acids, 2010 .

Loeser JD, Treede RD. The Kyoto protocol of IASP Basic Pain Terminology. Pain, 2008;137(3):473-7.

Luo ZD, Chaplan SR, Scott BP, et al. Neuronal nitric oxide synthase mRNA upregulation in rat sensory neurons after spinal nerve ligation: lack of a role in allodynia development. J Neurosci, 1999;19(21):9201-8. 
Maihofner C, Euchenhofer C, Tegeder I, et al. Regulation and immunhistochemical localization of nitric oxide synthases and soluble guanylyl cyclase in mouse spinal cord following nociceptive stimulation. Neurosci Lett, 2000;290(1):71-5.

Melzack R, Wall PD. Pain mechanisms: a new theory. Science, 1965;150(3699):971-9.

Merskey H, Albe-Fessard, D., Bonica, J.J., Carmon, A., Dubner, R.,, Kerr FWL, et al. Pain terms: a list with definitions and notes on usage. Recommended by the IASP Subcommittee on Taxonomy. Pain, 1979;6(3):249.

Meyer RAR, M.; Campbell, J.N.; Raja, S.N. Peripheral mechanisms of cutaneous nociception. In: McMahon SBK, M., editor. book title. Philadelphia: Elsevier, 2008;p3-34.

Millan MJ. The induction of pain: an integrative review. Prog Neurobiol, 1999;57(1):1-164.

Milligan ED, Zapata V, Chacur M, et al. Evidence that exogenous and endogenous fractalkine can induce spinal nociceptive facilitation in rats. Eur J Neurosci, 2004;20(9):2294-302.

Moncada S, Higgs EA. Molecular mechanisms and therapeutic strategies related to nitric oxide. Faseb J, 1995;9(13):1319-30.

Moncada S, Palmer RM, Higgs EA. Nitric oxide: physiology, pathophysiology, and pharmacology. Pharmacol Rev, 1991;43(2):109-42.

Moore PK, Oluyomi AO, Babbedge RC, Wallace P, Hart SL. L-NG-nitro arginine methyl ester exhibits antinociceptive activity in the mouse. Br J Pharmacol, 1991;102(1):198-202.

Morris R, Southam E, Braid DJ, Garthwaite J. Nitric oxide may act as a messenger between dorsal root ganglion neurones and their satellite cells. Neurosci Lett, 1992;137(1):29-32.

Olausson H, Cole J, Rylander K, et al. Functional role of unmyelinated tactile afferents in human hairy skin: sympathetic response and perceptual localization. Exp Brain Res, 2008;184(1):135-40.

Osborne MG, Coderre TJ. Effects of intrathecal administration of nitric oxide synthase inhibitors on carrageenan-induced thermal hyperalgesia. Br J Pharmacol, 1999;126(8):1840-6.

Payne B, Norfleet MA. Chronic pain and the family: a review. Pain, 1986;26(1):1-22.

Perl ER. Ideas about pain, a historical view. Nat Rev Neurosci, 2007;8(1):71-80.

Randall LO, Selitto JJ. A method for measurement of analgesia activity on inflamed tissue. Arch. Inst. Pharmacodyn., 1957;111:209-19.

Rexed B. The cytoarchitectonic organization of the spinal cord in the cat. Journal of Comparative Neurology, 1952;96:415-95.

Ruscheweyh R, Goralczyk A, Wunderbaldinger G, Schober A, Sandkuhler J. Possible sources and sites of action of the nitric oxide involved in synaptic plasticity at spinal lamina I projection neurons. Neuroscience, 2006;141(2):977-88. 
Schmidt R, Schmelz M, Forster C, et al. Novel classes of responsive and unresponsive C nociceptors in human skin. J Neurosci, 1995;15(1 Pt 1):333-41.

Schmidtko A, Tegeder I, Geisslinger G. No NO, no pain? The role of nitric oxide and cGMP in spinal pain processing. Trends Neurosci, 2009;32(6):339-46.

Schnitzler A, Ploner M. Neurophysiology and functional neuroanatomy of pain perception. J Clin Neurophysiol, 2000;17(6):592-603.

Sherrington CS. Observations on the scratch-reflex in the spinal dog. J Physiol, 1906;34(12): $1-50$.

Snider WD, McMahon SB. Tackling pain at the source: new ideas about nociceptors. Neuron, 1998;20(4):629-32.

Snyder SH, Dawson TM. Nitric oxide and related substances as neural messengers. In: Bloom FE, Kupfer DJ, editors. book title. New york: Raven Press, 1995;p609-18.

Sousa AM, Prado WA. The dual effect of a nitric oxide donor in nociception. Brain Res, 2001;897(1-2):9-19.

Tanabe M, Nagatani Y, Saitoh K, Takasu K, Ono H. Pharmacological assessments of nitric oxide synthase isoforms and downstream diversity of NO signaling in the maintenance of thermal and mechanical hypersensitivity after peripheral nerve injury in mice. Neuropharmacology, 2009;56(3):702-8.

Tao F, Tao YX, Mao P, et al. Intact carrageenan-induced thermal hyperalgesia in mice lacking inducible nitric oxide synthase. Neuroscience, 2003;120(3):847-54.

Tao F, Tao YX, Zhao C, et al. Differential roles of neuronal and endothelial nitric oxide synthases during carrageenan-induced inflammatory hyperalgesia. Neuroscience, 2004;128(2):421-30.

Torrão AS, Britto LR. Increased expression of nitric oxide synthase in visual structures of the chick brain after retinal removal. J Neurosci Res, 2004;78(1):123-31.

Unger JW, Lange W. NADPH-diaphorase-positive cell populations in the human amygdala and temporal cortex: neuroanatomy, peptidergic characteristics and aspects of aging and Alzheimer's disease. Acta Neuropathol (Berl), 1992;83(6):636-46.

Valtschanoff JG, Weinberg RJ, Rustioni A. NADPH diaphorase in the spinal cord of rats. J Comp Neurol, 1992;321(2):209-22.

Wang ZQ, Porreca F, Cuzzocrea S, et al. A newly identified role for superoxide in inflammatory pain. J Pharmacol Exp Ther, 2004;309(3):869-78.

Woolf CJ. Pain: moving from symptom control toward mechanism-specific pharmacologic management. Ann Intern Med, 2004;140(6):441-51. 
Woolf CJ. Central sensitization: uncovering the relation between pain and plasticity. Anesthesiology, 2007;106(4):864-7.

Woolf CJ, Mannion RJ. Neuropathic pain: aetiology, symptoms, mechanisms, and management. Lancet, 1999;353(9168):1959-64.

Yonehara N, Takemura M, Yoshimura M, et al. Nitric oxide in the rat spinal cord in Freund's adjuvant-induced hyperalgesia. Jpn J Pharmacol, 1997;75(4):327-35.

Zembowicz A, Hecker M, Macarthur H, Sessa WC, Vane JR. Nitric oxide and another potent vasodilator are formed from NG-hydroxy-L-arginine by cultured endothelial cells. Proc Natl Acad Sci U S A, 1991;88(24):11172-6.

Zhang X, Verge V, Wiesenfeld-Hallin Z, et al. Nitric oxide synthase-like immunoreactivity in lumbar dorsal root ganglia and spinal cord of rat and monkey and effect of peripheral axotomy. J Comp Neurol, 1993;335(4):563-75.

Zimmermann M. Ethical guidelines for investigations of experimental pain in conscious animals. Pain, 1983;16(2):109-10. 